Finance and Economics Discussion Series Divisions of Research \& Statistics and Monetary Affairs Federal Reserve Board, Washington, D.C.

\title{
Yesterday's Bad Times are Today's Good Old Times: Retail Price Changes in the 1890s were Smaller, Less Frequent, and More Permanent
}

\begin{abstract}
Alan Kackmeister
2005-18

NOTE: Staff working papers in the Finance and Economics Discussion Series (FEDS) are preliminary materials circulated to stimulate discussion and critical comment. The analysis and conclusions set forth are those of the authors and do not indicate concurrence by other members of the research staff or the Board of Governors. References in publications to the Finance and Economics Discussion Series (other than acknowledgement) should be cleared with the author(s) to protect the tentative character of these papers.
\end{abstract}




\title{
Yesterday's Bad Times are Today's Good Old Times: Retail Price Changes in the 1890s were Smaller, Less Frequent, and More Permanent
}

This paper compares nominal price rigidity in retail stores during two 28-month periods: 18891891 and 1997-1999. The 1889-1891 microdata price quotes show: 1. a lower frequency of price changes; 2. a smaller average magnitude of price changes; 3. fewer "small" price changes; and, 4. fewer temporary price reductions. These differences are consistent with the 1889-1891 period having a higher cost of changing prices resulting in less adjustment to transitory price shocks. Changes in the retailing environment that may have led to a higher cost of changing prices in 1889-1891 are discussed.

\author{
Alan Kackmeister \\ Federal Reserve Board of Governors \\ $20^{\text {th }}$ St. and C St. NW \\ Washington DC 20551 \\ alan.k.kackmeister@frb.gov
}

January 31, 2005

I would like to thank George Akerlof for encouragement, guidance, and countless suggestions. I would also like to thank Christina Romer, Barry Eichengreen, Catherine Wolfram, Peter Klenow, Chris Hanes, Bill Wascher, Paul Ruud, Jeff Frank, Steve Schutt, and many graduate students during my time at UC Berkeley for comments and suggestions. The views presented are solely those of the author and do not necessarily represent those of the Federal Reserve Board or its staff. 
In the good old times in which the economists of the preceding generation lived, and from which they drew their economic illustrations and ideas, [price] changes seldom occurred, and when they did take place were very limited in extent, and came so slowly into effect as to attract no attention. All common articles of consumption had fixed prices which often did not change for a lifetime, and if any dealer had attempted to charge more than custom demanded, it would have attracted the attention and aroused the indignation of the whole community. These conditions have been so altered that to-day a merchant must consult his paper each day before he can know where to purchase a stock at the best advantage. The consumer also must be on his guard or he will pay too much for his sugar or flour. Dress goods and clothing, even at retail, fluctuate so rapidly in value that a study of advertisements is essential to a careful purchaser.

\author{
Simon N. Patten \\ Professor of Political Economy \\ Wharton School of Finance and Economy \\ "The Stability of Prices" \\ Publications of the American Economic Association \\ January 1889
}

With a growing collection of microdata studies finding infrequent price changes, a next step is to ask whether price changes today are more frequent or less frequent in the present than in the past. ${ }^{1}$ The answer to this question may help explain differences in economic performance across time. For example, if price movements reflect market forces then declining nominal price rigidity - the time between price changes - may lead to improved resource allocation and higher productivity, and may have important implications for business cycles and the transmission of monetary policy.

As is related in the opening quote, over one-hundred years ago Simon Patten suggested price changes were much more frequent by 1889 than they were "in the good old times". Unfortunately, Patten did not include quantitative support for his assertion, and little timeseries data exists before 1889 to verify his claim. However, even at the end of Patten's period the long life of retail prices is anecdotally supported by Levy and Young's (2004) finding that the retail price of a 6.5 ounce Coke remained unchanged for the 73 years from 1886 to 1959 .

More recent studies using data from the 1950s through the 1980s, such as Cecchetti (1986) (magazine prices), Carlton (1986) (wholesale industrial goods prices), and Kashyap (1995) (apparel and outdoor goods prices from catalogs), find a shorter time between price changes - on the order of one year. Even more recently, studies using retail price data from the

\footnotetext{
${ }^{1}$ Among the studies looking at the frequency of price changes for the United States are: Carlton (1986), Cecchetti (1986), Kashyap (1995), Levy, et al. (1997), Bils and Klenow (2004).
} 
1990s suggest the time between price changes may have decreased to around a few months. ${ }^{2}$ However, these studies differ so substantially in coverage and sources that the apparent decline in price rigidity may be simply the result of different studies using different goods.

This leads to the central question of this paper: Has price rigidity declined over time? Specifically, from the today's perspective does 1889, Professor Patten's age of rapidly fluctuating prices, look like the "good old times" of highly rigid prices? To answer this question, goods from 1889-1891 are compared with similar goods from 1997-1999. For each of these two periods, broadly similar data sets are constructed covering retail price microdata over 28-months in 4 cities and up to 48 different product groups, including foods, household goods and clothing. Over forty thousand first-differenced observations are available in each of the two periods. As compared to 1997-1999, the data for 1889-1891 show:

(1) A lower frequency of retail price changes

(2) A smaller average magnitude of price changes

(3) Fewer "small" price changes, and

(4) Fewer temporary price reductions

Some changes in the retail environment that might explain these findings are discussed in the last section. Most of the differences between the 1889-1891 and 1997-1999 data are consistent with a higher cost of changing prices in 1889-1891 coupled with a high occurrence of temporary price shocks.

\section{Prior Microdata Studies and Wholesale vs. Retail prices}

Numerous prior studies, dating back at least to Mills (1927), have examined the frequency and size of price changes. A summary of results from some of these earlier studies is presented in Table 1. The estimated time between price changes varies widely, ranging from just over two weeks to nearly three-quarters of a century, while the absolute size of price changes extends from less than one percent to nearly thirty percent. ${ }^{3}$

The huge differences in products across the studies in table 1 make drawing conclusions about changes in the frequency or size of prices changes across time problematic. However, as noted previously, there appears to be less nominal price rigidity in the more recent studies of Bils and Klenow, and Levy, et al. than in the earlier studies of Cecchetti, Kashyap and Carlton.

\footnotetext{
${ }^{2}$ Bils and Klenow (2004), Levy, et al (1997).

${ }^{3}$ In all studies, observations where the price is unchanged are dropped from the calculation of the size of price changes.
} 
Unlike the other studies listed in table 1, Bezanson, et al. (1936) and Mills (1927) examine prices in more than a single time period, and these studies both also generally show a downward drift in the frequency of price changes within the periods they cover. However, both studies used wholesale rather than retail prices.

Wholesale prices suffer from three problems when attempting to ascertain the length of nominal price rigidity. First, collected list prices might not reflect actual transaction prices because wholesale products are often negotiated on a customer-by-customer basis. ${ }^{4}$ Second, the effective good received by the purchaser might change over time as varying delivery lags and other non-price means of allocation are common with wholesale goods. ${ }^{5}$ These two problems can result in a constant price being observed when a price change should be recorded, which will lead to an upward bias in the measurement of the length of nominal rigidity.

A third problem with wholesale prices is that wholesale prices are not unique. A single unit may be sold many times before retail. For example, during the earlier period in this paper at least three prices before retail were common: the price received by producers (or farmers); the price received by large wholesalers; and the price received by jobbers, the small scale wholesalers who bought from the large wholesalers and sold directly to the retail stores. Each of these prices may have different characteristics. ${ }^{6}$ The inclusion of large wholesale auction market prices, which are likely to exhibit little nominal rigidity, along with jobber prices may be the reason that price changes appear to occur much more frequently in the studies of Mills and Bezanson, et al.

Retail prices avoid most difficulties of wholesale prices. In retail markets price negotiation seldom occurs, customers usually receive their goods immediately, and a single unit of a product is sold at retail only once. These differences make retail prices preferable to wholesale prices in determining price rigidity.

Retail prices, however, do have some problems. Temporary stock-outs can lead to missing observations. Also, minor product specification changes may lead to the changed good being classified as a new item, and can thereby hide a price change. ${ }^{7}$ Further, retail prices tend to be heterogeneous with respect to brand and packaging sizes. The different brands and

\footnotetext{
${ }^{4}$ Stigler and Kindahl (1973).

${ }^{5}$ Carlton (1983, 1986), Morgenstern (1931), Dimand (2000), and Backman (1940 p. 485). Koelln and Rush (1993) in their critique of Cecchetti (1986) note a similar concept can apply to retail goods, for example when the number of pages in a magazine is reduced.

${ }^{6}$ Backman (1940 p. 487) discusses market structure and price rigidity.

${ }^{7}$ An example of this type of a minor product change occurred in 2001 when Kleenex reduced the number of tissues in a box from a 250 to a 230 but kept the same price. (Consumer Reports (2001)) Tissues are not included in any of the product groupings, and it is not known if minor specification changes hid price changes in any of the actual goods sampled.
} 
package sizes may have different characteristics with respect to nominal price rigidity, and the heterogeneity may itself lead to greater price rigidity as firms may have more market power. The extent of these problems among the product sampled here is unknown, but minor product specification changes and product heterogeneity - which lead to longer estimates of nominal price rigidity - are probably more common in the 1997-1999 data sample, suggesting that adjusting for them would strengthen the results found later in the paper.

\section{An Overview of the Time Periods and Data}

This study focuses on pricing across time, and therefore it is necessary to control for factors that are not necessarily related to long-run changes across time but might cause different pricing patterns between the two samples. Chief among these are different macroeconomic conditions and data sampling methods in the two periods. The choice of data has minimized these two potential problems. The macroeconomic conditions in 1889-1891 and 1997-1999, while not identical, are similar enough that they are unlikely to cause major differences in the microdata. For example, neither period includes a wartime economy, a sustained recession, or a severe crash in the financial markets. (See table 2.) Nor were price controls or price supports important during these periods. Also, both periods have similar inflation rates that are among the lowest inflation episodes in the past one hundred and fifty years. ${ }^{8}$ The similarity in inflation rates is extremely important when comparing the frequency of price changes across time because aggregate inflation is one of the main causes of price changes. In a literature review Taylor (1999) states:

The frequency of wage and price changes depends on the average rate of inflation... $[\mathrm{P}]$ rices at small businesses, industrial prices, and even the prices of products like magazines are adjusted more quickly when the rate of inflation is higher. This dependency of price and wage setting on events in the economy is one of the more robust empirical findings in the studies reviewed here. (p. 1021)

Further, the retail price microdata are surprisingly consistent on methodological grounds. Both data sets are actual price quotes of retail establishments sampled by the Bureau of Labor Statistics at a given point in each month. In both sets the prices quoted should closely reflect transaction prices. $^{9}$

\footnotetext{
${ }^{8}$ Reliable estimates of aggregate consumer price inflation are not available for the 1889-1891 period, therefore table 2 shows wholesale price inflation.

${ }^{9}$ There are a few relatively minor differences in methodology which are not expected to cause a problem, such as collecting the prices every month, which is the current practice, versus collecting the prices for the entire 28-month period from the merchant's transaction records at the end of the period, which was the
} 
However, methodologically-consistent time series of retail price microdata are not readily available, and this has hampered the inclusion of additional time periods. Over the past 110 years, a handful of different institutions have created retail price indexes for the United States. Most of the microdata used in creating these indexes has been lost or destroyed. To my knowledge, there exist only four multi-good datasets of monthly time-series retail price microdata for the United States, each covering only a very limited number of goods and years. This study relies on the two broadest and most comparable sources of U.S. retail price microdata: the 1892 Aldrich Report [Aldrich (1892)], an exhaustive study conducted by the then-recently-formed Bureau of Labor Statistics covering, among other things, retail prices in 1889-1891, and the available microdata underlying the Bureau of Labor Statistics' Consumer Price Index, for which I have obtained a selection covering 1997-1999. ${ }^{10}$

The 1997-1999 dataset was specifically constructed to conform as closely as possible to the available data from the 1889-1891 period. Starting and ending dates were chosen to match the length and seasonality of the earlier data. Both datasets start in June and end in September 27 months later. Products were chosen to maximize the number of comparable product groups common to both samples. Localities were chosen to maximize the number of localities with monthly price quotes in both samples.

Twenty-seven food products, seven clothing products, and fourteen household and hardware products, for a total of forty-eight products, are common to both the Aldrich report and current BLS CPI sample. Table 3 lists these 48 products. There also are four geographic locations surveyed monthly in both samples: New York, Chicago, Los Angeles, and Newark.

Even within relatively disaggregated locations and products, substantial differences among the sampled items is present within a group. For example, stores in high and low rent areas might exist within a single location group, while only broadly related products might exist within a single product group. ${ }^{11}$ Also, various sizes and brands of the same product might exist within a single product group. ${ }^{12}$ For the purposes of this paper, it is assumed that all goods within a given product or location group have similar price adjustment characteristics.

Basic statistics for the two datasets, shown in table 4, point out two important features of the data. First, food prices, which tend to be volatile, comprise a larger share of the 1997-

practice for the 1889-1891 data. Methodology is described more fully in the data appendix and Appendix Table A3.

${ }^{10}$ Microdata underlying the U.S. CPI currently exists only back to the late 1980s. All four potential sources of U.S. retail price microdata are described in the data appendix.

${ }^{11}$ For example, onions, cabbages, and turnips all are part of the fresh vegetables product group.

${ }^{12}$ This variation in sizes and brands makes price level dispersion for a single product impossible to calculate. 
1999 data. This compositional difference will bias a simple average towards finding more frequent price changes in 1997-1999. Second, both periods display a low unweighted average of first-differenced log prices, and only slightly more upward price changes than downward price changes. This reinforces the belief that inflation does not importantly influence the results.

\section{How the 1890s differed from the 1990s}

\section{A lower frequency of price changes}

Nominal price rigidity in this paper is measured by the frequency of price changes (which is the share of first-differenced observations where the price in time $t$ does not equal the price in time $t-1){ }^{13} \quad$ A higher frequency of price changes represents less nominal price rigidity. Using the frequency of price changes, rather than average (or median) length of time between prices changes, allows the inclusion of observations for which the beginning and/or ending of the spell are missing from the dataset.

The lower overall frequency of price changes in the 1889-1891 sample is apparent from the first two lines of table 4 . The number of price changes in the 1889-1891 data is one-fifth of that in the 1997-1999 data despite a similar number of first-differenced observations.

To check that the lower frequency of price changes in the 1889-1891 sample is not simply a result of the difference in the share of food goods, or other differences in products, locations, or seasonality between the two datasets, each observed price first-difference is classified into a cell based on the location, product, and month. Then, the share of prices changing in a given cell in the $19^{\text {th }}$ century sample is compared with the corresponding cell in the $20^{\text {th }}$ century sample. ${ }^{14}$ Dropping cells with less than 5 observations in each period leaves 1290 cells containing more than 15,000 observations in each period for comparison.

This cells-based approach also suggests that prices changes were less frequent in the earlier period. 909 of the 1290 cells, or $70 \%$, have a lower frequency of price changes in 18891891 than in 1997-1999. By comparison, only 254 cells, or 20\%, show a higher frequency of

\footnotetext{
${ }^{13}$ As observations are monthly, the inverse of the frequency of price changes is a slightly-upward-biased measure of the expected time between price changes.

${ }^{14}$ To avoid multiple counting the months are numbered sequentially. For example, cells from the first month of the 1889-1891 sample, June 1889, are only compared with cells from the first month of the 19971999 sample, June 1997. Cells from July 1889 are compared to cells from July 1997, etc. The use of cells based on location, products, and months is conceptually similar to the approach currently used to create the lowest level indices in the CPI.
} 
price changes in the earlier period. The remaining 127 cells, or $10 \%$, show the same frequency in each period. ${ }^{15}$

Differentiating observations only by location, by product, or by month, rather than all three attributes, gives a more readily accessible view of the data. This view of the data is shown in the three panels of figure 1.

In 43 of the 48 product groups the frequency of price changes was lower in 1889-1891 than in 1997-1999. These product groups are shown in the top panel of figure 1.

The lower frequency of price changes in 1889-1891 is much more pronounced for nonfood goods than for the food goods - a result of the extreme rigidity displayed by non-food goods in the 1889-1891 sample. The twenty-one non-food product groups in the 1889-1891 sample collectively contain 20,347 observations, but only 135 price changes. This amounts to an average of one price change every 12-1/2 years!

A handful of food goods also displayed substantial nominal price rigidity in the 18891891 sample. In the seven food product groups of coffee, tea, milk, beer, cornmeal, bread, and salt and seasonings, collectively consisting of over 7,000 observations, only 38 price changes are observed - an average of one price change every 15 years.

The few goods that had a fairly high frequency of price changes in the 1889-1891 period - eggs, sugar, butter, potatoes, and tomatoes - are staple goods, which might have been used as loss leaders to bring in customers. Another possible cause of the high frequency of price changes for eggs and butter in 1889-1891 is the presence of a strong seasonal cycle in prices of these two products. This seasonality has since declined as the result of cheaper refrigeration. ${ }^{16}$

Pooling observations for a given location or month also shows a lower frequency of price changes in the earlier period. The frequency of price changes rose in each location between the two periods, though there is substantial variation in the frequency of price changes across the different locations. (Figure 1B.) Also, every month in the 1997-1999 sample has a higher frequency of price changes than the corresponding month in the 1889-1891 sample, and there is no strong seasonality in the frequency of price changes in either period. (Figure 1C.)

Pooling all observations and examining the Kaplan-Meier survival function shows just how rigid prices were in the 1889-1891 data. (Figure 2.) The Kaplan-Meier survival function gives the probability of a price remaining unchanged for a given length of time. ${ }^{17}$ In $1889-1891$

\footnotetext{
${ }^{15}$ This usually means that no price change was observed in either cell.

${ }^{16}$ Goodwin, Grennes, and Craig (2002) show refrigeration had a strong effect on dampening the swings in butter prices.

17 The Kaplan-Meier methodology does not depend on a functional form. At each point in time the marginal probability of a price remaining unchanged between months $t$ and $t+1$ is the share of prices with
} 
the probability that a spell of nominal rigidity would extend at least 28 months was greater than 50 percent. By comparison, the likelihood that spell of nominal rigidity would last at least 28 months in 1997-1999 was less than 20 percent. Moreover, for every length of time, the share of price quotes remaining unchanged is higher in 1889-1891 than in 1997-1999 and the 95 percent confidence intervals (not shown) do not overlap.

The various methods of cutting the data all suggest that price changes were much more frequent in 1997-1999 than in 1889-1891. From today's perspective, Professor Patten's age of rapidly fluctuating prices looks like the "good old times" of nominal price rigidity.

Before tackling a few possible explanations for the change in nominal rigidity, it will be useful to point out some other differences between the 1889-1891 and 1997-1999 data.

\section{$A$ smaller average magnitude of price changes}

Half of the nominal rigidity studies in listed table 1 also look at the average absolute size, or magnitude, of price changes. If firms use state dependent, or S-s, pricing strategies and shocks to the optimal price are continuous and long-lasting, then the magnitude of price changes may be a better measure of microdata price inflexibility than the frequency of price changes.

The magnitude of price changes is measured here as the absolute value of the logarithmic percent change in the price, $a b s\left(\ln \left(\frac{p_{t}}{p_{t-1}}\right)\right)$. Cases for which the price is unchanged between time $t$ and $t-1$ are removed. Taking the price change as a share of the good's price, as is done here, adjusts for the increase in the general price level between the two periods. The tendency for more expensive items to exhibit larger price changes in nominal dollar terms suggests that the approximately 6000 percent rise in the overall price level between the two time periods would lead to finding substantially larger price changes in the 1997-1999 period in nominal dollar terms.

Pooling all 2,367 price changes in the 1889-1891 data and all 12,709 price changes in the 1997-1999 data, the average magnitude of a price changes is smaller in 1889-1891 than in 19971999, $16.1 \%$ compared to $24.9 \%$. The difference between the periods is substantial, but not as dramatic as was the difference in the frequency of price changes.

Similar to the procedure done with the frequency, observations can be segregated into cells based on product, location, and month, and only cells containing three or more price

observations in both months $\mathrm{t}$ and $\mathrm{t}+1$ which remain unchanged. The survival function is a cumulation of the marginal probabilities. 
changes in each data set are compared. ${ }^{18}$ The 196 remaining cells contain 896 price changes in 1889-1891 and 1,694 prices changes in 1997-1999. Of these 196 cells, 133, or 68 percent, show a smaller average magnitude of price changes in 1889-1891 period, while in the other 63 cells the average magnitude was larger in 1889-1891.

The three panels of figure 3 differentiate observations by product, by location, and by month. The top panel shows that three-quarters of the products had a smaller magnitude of price changes in the earlier period, though the size of price changes varies widely by product. The bottom two panels of figure 3 show that for each location and every month the magnitude of price changes was smaller in 1889-1891 than in 1997-1999.

In both periods products that changed price more often were more likely to have slightly larger price changes. The relationship between the frequency and size of price changes is plotted in figures 4 and 5 using observations grouped by location and product. The positive relationship between the frequency and size of price changes is more robust in 1997-1999 than it is in 18891891. In the earlier data, the positive correlation is almost entirely driven by the price of tomatoes.

As with the frequency of price changes, the change in the magnitude of price changes is consistent across different ways of looking at the data. In each method of slicing the data, the magnitude of price changes was somewhat lower in 1889-1891 than in 1997-1999.

\section{Fewer very small price changes}

Even though the average magnitude of prices changes may have been lower in 1889-1891 than in 1997-1999 there appears to have been fewer very small price changes in 1889-1891. Pooling all price changes together, the cumulative distribution of the size of price changes is shown in figure 6. A noticeable trait of the 1889-1891 data is the fairly sharp change in the slope of the cumulative distribution as the size of the change approaches zero. The flatness suggests price changes that are a small amount of the good's price are avoided. ${ }^{19}$ This behavior is predicted by a cost to changing prices, such as a menu cost. In 1997-1999 there is little observable flatness around zero, suggesting price changes less than a couple percent in size were no less likely to occur than price changes a few percentage points larger.

\footnotetext{
${ }^{18}$ Changing the threshold from three or more observations substantially changes the number of possible cell comparisons, but has little effect on the share of cells for which the magnitude of price changes increased.

${ }^{19}$ It should be emphasized that "small" is defined in terms of the percentage change in the good's price. As noted earlier, the size of price changes in dollar terms has increased as a result of the around 6,000 percent increase in overall prices that occurred over the 118 years between the two time periods.
} 
The paucity of small price changes in 1889-1891 is even more apparent in figure 7 . This figure displays the share of price changes (vertical axis) less than a given absolute size (the horizontal axis). In 1889-1891 the share of price changes that were less than 2.5 percent in magnitude was less than a fifth the share in 1997-1999. Also, almost no price changes in the earlier period were less than 1.5 percent in magnitude. Such small price changes were not uncommon in the 1997-1999 period.

Monetary indivisibility is an alternative to a price changing cost for explaining the lack of small price changes in 1889-1891. Despite the large change in the price level since 1889, the smallest coin minted in the US in 1889 had the same nominal value as the smallest coin currently minted-1-cent. This likely discouraged some merchants from making price changes less than 1-cent in magnitude. However, in the 1889-1891 data, 2-cent and 5-cent price changes were each slightly more common than 1-cent price changes, which would not be expected if monetary indivisibility were significant problem. ${ }^{20}$ Further, with some of the goods in the earlier period being sold in bulk, price changes less than 1-cent in size were not uncommon, about 7 percent of price changes in 1889-1891 were less than 1-cent in magnitude.

\section{Less use of Temporary Price Reductions (Sales) and More Price Churning}

Lal and Matutes (1994) cite a survey of supermarket managers suggesting temporary price reductions became more important during the 1980s. How important are temporary price reductions in explaining the higher frequency of price changes observed in 1997-1999?

Only one- and two-month temporary price reductions are considered in this paper. A one-month temporary price reduction is defined as a drop in price perfectly counteracted the following month. ${ }^{21}$ A two-month temporary price reduction is a drop in price taken back in either one of the next two months.

It is possible that this definition of a temporary price reduction does not catch all shortterm sales of goods. For example, the definition would miss a good put on sale at a lower price before moving to a new, higher-than-before "regular" price. But, using higher frequency data, Warner and Barsky (1995) find 51 out 62 temporary price reductions in their sample were

\footnotetext{
${ }^{20}$ In the 1889-1891 data, price changes that had a nominal value of 2-cents accounted for 20 percent of the price changes, followed by 5 -cents (19 percent of price changes), 1-cent (17 percent), 3-cents

(10 percent), 1/2-cent (5 percent), and 10-cents ( 5 percent).

${ }^{21}$ The price in month two is less than in month one, but in month three it returns to the price in month one. Observations where a reduction in price occurred in the last sampled month are dropped since it is impossible to determine if the price change was a temporary price reduction or a more permanent price reduction. Hosken, Matsa, and Reiffen (2000) use a similar definition.
} 
exactly reversed, suggesting that this definition of temporary price reductions probably catches most sales.

Similar to temporary price reductions are price markdowns. Price markdowns start with a high initial price that is gradually reduced over time. Markdowns differ from temporary price reductions in that the price never increases until the product is sold out. They are common in goods for which fads or fashions change quickly and production runs are short. ${ }^{22}$ Few of the product groups in the sample fit this description and therefore significant effects from price markdowns are unlikely.

Table 5 shows the frequency and size of price changes for a pooling of all observations before and after filtering out various combinations of price markdowns and temporary price reductions. Filtering out temporary price reductions decreases the frequency of price changes much more in 1997-1999 than in 1889-1891, suggesting an increase in the use of temporary price reductions. About 15 percent of price changes in 1889-1891 were either a temporary price reduction or the reversal of the price reduction, compared with 40 percent in 1997-1999. Nonetheless, even excluding temporary price reductions and price markdowns, price changes were at least four times more common in 1997-1999 than in 1889-1891.

Excluding price markdowns and temporary price reductions has less effect on the magnitude of price changes. Removing temporary price reductions decreases the magnitude of price changes about 2 to 3 percent in 1997-1999, suggesting that temporary price reductions during that period were somewhat larger in magnitude than normal price changes. In contrast, removing temporary price reductions has a negligible effect on the average magnitude of price changes in 1889-1891.

An alternative view of temporary price changes can be seen by looking at the probability of two consecutive price changes of the same sign. In a standard S-s pricing model with permanent shocks to the optimal price, and no trend drift rate in the optimal price, the probability of the next price change being in the same direction as the previous price change is 50 percent. If there is a trend drift rate in the optimal price, this probability will be higher than 50 percent, whereas if changes in the optimal price are temporary the probability may be below 50 percent. In the 1889-1891 period, the next price change was somewhat more likely to be in the same direction as the previous price change, while consecutive price changes were less likely to be in the same direction in 1997-1999. (Table 6.) This finding suggests that price changes were more permanent in 1889-1891 than they were in 1997-1999. 


\section{Discussion}

To understand the potential causes of the differences in price adjustment in 1889-1891 and 1997-1999, it is useful to summarize some of the major changes that have taken place in the retailing environment during the last century. ${ }^{23}$

First, stores today are much larger than they were in the late 1880s, both in the number of employees and in the number of goods offered for sale. In 1889-1891 most stores were quite small and concentrated on a few products. For example, in 1889 the grocery chain A\&P sold mostly tea, coffee, butter, sugar and baking powder. ${ }^{24}$ By 1928, the number of items carried by the average grocery store increased to 867 . This jumped to around 3,000 items in each store in 1946 and to 6,800 in $1963 .{ }^{25}$ Today, conventional supermarkets carry around 25,000 items and include a bakery, a meat counter, and a large selection of non-food items. ${ }^{26}$ Measuring store size by the number of employees shows a similar increase. Quantitative information for 1890 is scare, but Nystrom $(1919,1930)$ suggests that stores were usually a one or two man operation. The increase in the size of supermarkets since 1929, when quantitative figures first became available, can be seen in Figure 8, which displays employees per food retailer. By this measure the size of grocery stores increased almost tenfold between 1929 and 1997.

Another difference between retailing in 1889-1891 and 1997-1999 is that the industry is much more concentrated today. Although there were exceptions with a few large department stores in New York (Macy's, Lord \& Taylor, and Bloomingdale's) and Chicago (Marshall Fields), the retail business was fragmented in 1890. Only six grocery chains, one drug chain, and ten other retail chains were operating in the United States in $1890 .{ }^{27}$ A\&P, the largest of these chains, owned over a hundred grocery stores scattered throughout the eastern half of the U.S. However, even in its largest market, New York, A\&P operated only about 25 stores. $^{28}$ Kroger, a grocery chain based in Cincinnati, operated only seven stores in 1890. ${ }^{29}$ Barger (1955) estimates that chain stores held a miniscule fraction of grocery business in the U.S. before

\footnotetext{
${ }^{22}$ Pashigian (1988)

${ }^{23}$ This section concentrates on the food retailing industry, since most of the products used in this study are sold in supermarkets, but the broad outline should be applicable to changes throughout the retail goods industry.

${ }^{24}$ Bullock (1933) p. 61-62. While the stores sold only a few types of products, they would typically carry several varieties of each product.

${ }^{25}$ National Commission on Food Marketing (1966) p.2. The head of Kroger cites similar figures in Hall (1957) p.26.

${ }^{26}$ Food Marketing Institute. Supermarket Facts: Industry Overview 2001

(http://www.fmi.org/facts_figs/superfact.htm)

${ }^{27}$ A chain is defined as two or more stores under the same management. Historical Statistics of the United States p.836 and 847.

${ }^{28}$ Bullock (1933) p.61-62
} 
$1900 .^{30}$ Since this earlier time chain stores have accounted for an ever-rising share of the grocery industry. Chain stores' share of grocery sales rose from around 20 percent of the grocery business in 1909 to 40 percent in the mid-1930s to over 70 percent during the $1980 \mathrm{~s}^{31}$

A third difference in the retailing environment is the weakening of the personal relationship between the retailer and customer. In 1889-1891, with most retailing occurring in small shops, a relationship existed between the retailer and the customer. Part of this relationship was probably personal. Without refrigerators, grocery shopping was done nearly every day. And, being a one or two-man store, the shopkeeper probably got to know his customers personally. Another part of the relationship may have been brought on by business concerns. For instance, the retailer often supplied credit to the customer, and the inability to collect on this credit was the downfall of many grocery stores. Because transportation was difficult and carrying purchases was burdensome, retailers usually delivered the purchases to the customer's home at no extra charge. This gave customers a reason to stay loyal to the retailer. Regular customers might be placed near the beginning of a delivery route, getting the butter when it was still hard, while customers with less of a relationship might not get their goods until the end of the delivery route, when the butter was getting soft. The importance of the retail relationship in the late-1800s was noted by the editor of the American Grocer in 1896:

The grocery business is, perhaps more than any other, dependent for success or failure upon the individuality of the man engaged in it, even more than his business methods. If he wins the confidence of customers by keeping only good things, selling them at reasonable prices, being obliging and prompt in his deliveries and is reasonably careful about given credits, he will command and hold patronage. ${ }^{32}$

The few surveys available document declining customer loyalty to a particular store over the last century. The percentage of supermarket shoppers patronizing one store exclusively fell substantially in the post-war years, from 41 percent in 1954 to 29 percent in 1961 to 17 percent in $1965 .^{33}$ More recently, shoppers have become more willing to change the supermarket where they do most of their shopping. The percentage of shoppers changing their supermarket in the past year jumped from 18.2 percent in 1979-1980 to between 24 and 27 percent from 1990 to

\footnotetext{
${ }^{29}$ Lebhar (1963) p.396

${ }^{30}$ Barger (1955, p. 148);

${ }^{31}$ Barger (1955, p. 148), Chain Store Age (1950) p.J3. Nielsen (1985, 1989 p.4).

${ }^{32}$ New York Daily Tribune, October 11, 1896, (sect III, p15, col7)

${ }^{33}$ Schapker (1966). Table 1, p. 47. While the surveys continued for a number of additional years, the question seems to have been dropped.
} 
1994. In almost all years, the main reason for switching stores was lower prices at the new store. $^{34}$

A final difference in the retail environment is that the share of income spent on the goods covered in this study has declined substantially. Although food goods make up most of the observations in this study, the share of food in consumer expenditures has dropped from 40 percent in 1889-1891 to approximately 10 percent in 1997-1999.

These four changes in retailing structure (larger stores, greater industry concentration, declining customer-retailer relationship, and declining importance of food) have probably reduced the cost to changing prices. Larger stores, by carrying more products and employees, can exploit economies of scale in changing prices. Empirically, Buckle and Carlson (2000) find larger firms change prices more often. Similarly, the increase in industry concentration may also have lowered the cost of changing prices because many chain store pricing decisions are made above the store level. This allows the managerial costs of deciding when and by how much to change prices to be spread across many stores. Ball and Mankiw (1994) suggest that managerial costs are much larger than menu costs, a point echoed in the empirical work of Zbaracki, et al. (2004). The decline in the relationship between the retailer and the customer and the decline in the importance of food in consumers' expenditures also effectively lowered the cost of changing prices by lessening the chance of, in Patton's (1889) words, "arousing the indignation" of customers and thereby losing their business when price increases occurred.

If the cost of changing prices was higher in 1889-1891 than in 1997-1999 most standard models of price adjustment would find the less frequent price changes and fewer "small" price changes that were observed in the data. But, standard pricing models with permanent shocks would not predict the smaller average magnitude of price changes observed in 1889-1891, or the use of temporary price reductions that have become more prevalent in the recent period.

We can reconcile these last two findings if we assume that a significant share of the shocks to the profit maximizing price are temporary. Take a simple time-dependent pricing example: Assume the optimal price follows a moving average of independent standard normal shocks, $p_{t}^{*}=\mu_{t}+\mu_{t-1}$. By definition, the firm would charge the optimal price in a perfectly frictionless world. However, say that the firm must pay a cost, $C$, to see the realized value of the shocks and the resulting optimal price. In practice, this cost could come about because the firm must expend labor to interpret the effect of changes in supply costs or customer buying

\footnotetext{
${ }^{34}$ Burgoyne (1980), Food Marketing Institute (1994). These are the only surveys I have found asking this question. In one year, 1990, the top reason for switching grocery stores was that the new store was closer or had a more convenient location, possibly the result of a move by the respondent.
} 
habits on the price the firm should charge. In other words, the cost, $C$, is an administrative cost of determining the best price to charge, and not a true menu cost. After paying the price determination cost, there is no additional cost to changing prices. Once the firm pays the cost $C$, they observe the shock to the optimal price and then set the price for the current period, $p_{t}$. They continue to charge the price $p_{t}$ until the next time the firm pays the cost to observe the optimal price. Finally, the per period loss from maintaining a price that deviates from the optimal price is the square of the deviation, $\left(p-p_{t}^{*}\right)^{2}$, and there is no inflation or other discounting of losses.

Assume that the firm initially chooses to observe the optimal price every third period, and changes their price every time the optimal price is observed. The frequency of price changes is then $1 / 3$. To minimize the per period loss, the firm will set the actual price to the average expected optimal price. With the firm changing price every third period, this is:

$$
p_{0}=\frac{E_{0}\left(p^{*}\right)+E_{0}\left(p^{*}\right)+E_{0}\left(p^{*}\right)}{3}=\frac{1}{3}\left(E_{0}\left(\mu_{0}+\mu_{-1}\right)+E_{0}\left(\mu_{1}+\mu_{0}\right)+E_{0}\left(\mu_{2}+\mu_{1}\right)\right)=\frac{2}{3} \mu_{0}+\frac{1}{3} \mu_{-1},
$$

where the last equality occurs because shocks are mean-zero in expectation. Given this actual price, the expected magnitude of price changes (measured here by the expected squared size of price changes) is:

$$
E\left(p_{3}-p_{0}\right)^{2}=E\left(\left(\frac{2}{3} \mu_{3}+\frac{1}{3} \mu_{2}\right)-\left(\frac{2}{3} \mu_{0}+\frac{1}{3} \mu_{-1}\right)\right)^{2}=1 \frac{1}{9} \sigma_{\mu}^{2} .
$$

Finally, the expected average per period loss from having a constant price plus the cost of changing prices is $\frac{E\left(\left(p_{0}-p_{0}^{*}\right)^{2}+\left(p_{0}-p^{*}\right)^{2}+\left(p_{0}-p_{2}\right)^{2}\right)}{3}+\frac{C}{3}=1 \frac{12}{27} \sigma_{\mu}^{2}+\frac{C}{3}$.

Next, assume the firm changes price every other period. The frequency of price changes then increases to $1 / 2$. The firm will set its actual price to the average expected optimal price in the next two periods: $p_{0}=\frac{E_{0}\left(p_{0}^{*}\right)+E_{0}\left(p_{1}^{*}\right)}{2}=\frac{1}{2}\left(E_{0}\left(\mu_{0}+\mu_{-1}\right)+E_{0}\left(\mu_{1}+\mu_{0}\right)\right)=\mu_{0}+\frac{1}{2} \mu_{-1}$. The expected per period loss from following this policy of changing price every other period is $\frac{E\left(\left(p_{0}-p_{0}^{*}\right)^{2}+\left(p_{0}-p_{1}^{*}\right)^{2}\right)}{2}+\frac{C}{2}=1 \frac{1}{4} \sigma_{\mu}^{2}+\frac{C}{2}$, which is lower than the cost of changing prices every third period if $\frac{C}{\sigma_{\mu}^{2}}<\frac{6}{7}$. This suggests that, for a given size of temporary shocks, a lower cost of price changes will increase the frequency of price changes, a result that occurs in nearly all price setting models. However, the expected size of price changes when the changing price every other period is $E\left(p_{2}-p_{0}\right)^{2}=E\left(\left(\mu_{2}+\frac{1}{2} \mu_{1}\right)-\left(\mu_{0}+\frac{1}{2} \mu_{-1}\right)\right)^{2}=2 \frac{1}{2} \sigma_{\mu}^{2}$, which is larger than the size of price changes when setting price every third period. When price changes become more frequent, price changes become larger because firms now follow the up and down patterns that occur with temporary shocks rather than smoothing through the short-run volatility. The 
transitory shocks will also lead to the more temporary nature of price changes seen in the 19971999 data.

Figure 9 shows how the size of price changes relates to the persistence of shocks in a version of this time-dependent example where shocks occur continuously and time between price changes is also allowed to vary continuously. When shocks to the optimal price are permanent, reducing the time between price changes always leads to a decrease in the magnitude of price changes. On the other hand, when shocks to the optimal price are temporary, reducing the time between price changes leads to an increase in the magnitude of price changes if the initial time between price changes is relatively long. The intuition behind this result is that when shocks are temporary, and the length of time between price changes is long, little attention is paid to the current shocks in setting the price because the shocks will be long gone by the time of the next price change.

One additional feature of this simple model is that magnitude of price changes can be larger when shocks are temporary than when shocks are permanent. Consider the discrete-time example, but now with permanent shocks. In this case, when changing their price the firm will set it equal to the current optimal price. When changing price every other period this implies that the expected size of price changes is:

$$
E\left(p_{2}-p_{0}\right)^{2}=E\left(p{ }_{2}-p{ }_{0}^{*}\right)^{2}=E\left(\left(p{ }_{0}^{*}+\mu_{2}+\mu_{1}\right)-p{ }_{0}^{*}\right)^{2}=2 \sigma_{\mu}^{2}
$$

which is smaller than the $2 \frac{1}{2} \sigma_{\mu}^{2}$ size of price changes that occurred when shocks were temporary and firms changed price every other period.

That temporary shocks can sometimes lead to larger price changes than permanent shocks is also visible in figure 9. If shock persistence is long relative to the time between price changes, then temporary shocks will lead to larger price changes than will permanent shocks. Larger price changes in response to temporary shocks is also consistent to what was found in the data on table 5 . There the size of price changes decreased when temporary price reductions were filtered out of the 1997-1999 data.

Intuitively, temporary shocks can lead to larger price changes than permanent shocks because temporary shocks create a more variable change in the optimal price over short-horizon. When shocks are temporary, at any given instance a new shock occurs and an old shock disappears, each of which adds variance to the change in the optimal price. When shocks are 
permanent old shocks never disappear, and only new shocks perturb the optimal price making short-term changes in the optimal price less variable. ${ }^{35}$

Before concluding, it should be emphasized that the results presented in this paper refer to microdata prices not to aggregate prices. Changes in the cross-correlation of prices or changes in the composition of output may make aggregate rigidity results different from those found in this paper. For example, Hanes (1998, 1999) suggests that the economy has become more processed over the last one hundred years. He also suggests (as do Bils and Klenow (2004) and Thompson and Wilson (1999)) that processed goods are more rigid than unprocessed goods.

\section{Conclusion}

That nominal price rigidity may have declined over time is suggested when comparing the handful of previous studies and anecdotal evidence. On the other hand, this apparent decline of nominal price rigidity could have been an artifact of inconsistencies in coverage and sources across the different studies. The results presented here suggest this probably is not the case, and nominal price rigidity likely has declined. Using consistent data in two periods widely separated in time, this paper found nominal price rigidity in 1997-1999 was substantially less than in 1889-1891. The decline in nominal price rigidity is robust across the goods, months, and locations matched across the two periods. Further, the decline does not appear to be the result of differences in aggregate inflation rates.

Additional findings include an increase in the average magnitude of price changes between 1889-1891 and 1997-1999, though the difference between the two periods is less dramatic than is the difference in nominal price rigidity. Finally, small price changes and temporary price reductions have become more common in the recent period.

These findings are consistent with a model in which shocks to the optimal price are transitory and in which the cost of changing prices decreased between 1889-1891 and 1997-1999. The cost of changing prices likely fell between the two periods as a result of changes in the retailing environment, which included larger stores, greater industry concentration, the declining customer-retailer relationship, and the declining importance of food.

\footnotetext{
${ }^{35}$ If the optimal price followed a mean-reverting autoregressive process, rather than a moving average process, then the expected size of price changes would converge to the permanent shock case as shocks became more persistent. This does not occur with the moving average shock example shown. Further, an analytically-intractable S-s model with temporary shocks is also likely to find that price changes in response to temporary shocks are larger than price changes in response to permanent shocks. This is because the additional profit (prior to deducting the cost of the price change) from a temporary price
} 
In sum, from today's perspective, Professor Patten's age of highly variable prices looks like the good old times of nominal price rigidity.

change would have to pay the menu cost twice (once for the price increase and once the price decrease) whereas the additional profit from a permanent price change would only have to pay the menu cost once. 


\section{References}

Aldrich, Nelson. (1892) Retail Prices and Wages. Committee on Finance. Senate. $52^{\text {nd }}$ Congress. $1^{\text {st }}$ Session. Report 986. Washington, DC: U.S. Government Printing Office. Parts 1-3.

Backman, Jules. (1940) "The Causes of Price Inflexibility." The Quarterly Journal of Economics, Volume 54, Number 3. May, 474-489.

Ball, Laurence and N. Gregory Mankiw. (1994) "A Sticky-Price Manifesto." Carnegie Rochester Conference Series on Public Policy. Volume 41. Number 0. December, 127-151.

Barger, Harold. (1955) Distribution's Place in the American Economy since 1869. National Bureau of Economic Research. General series, no.58. Princeton University Press, Princeton.

Bezanson, Anne, Robert D. Gray, and Miriam Hussey. (1936) Wholesale Prices in Philadelphia 1784-1861. University of Pennsylvania Press. Philadelphia.

Bils, Mark, and Peter Klenow. (2004) "Some Evidence on the Importance of Sticky Prices." Journal of Political Economy. 112 October, 947-985.

Buckle, Robert A., and John A. Carlson. (2000) "Menu Costs, Firm Size and Price Rigidity." Economics Letters. Volume 66, Issue 1. January, 59-63.

Bullock, Roy J. (1933) "History of the Great Atlantic \& Pacific Tea Co. Since 1878." Harvard Business Review. Volume12, Number 1. October. Pp. 59-69

Burgoyne, Inc. (1980) National Study of Supermarket Shoppers (Census Profile) Cincinnati, Ohio.

Carlton, Dennis W. (1983) "Equilibrium Fluctuations when Price and Delivery Lag Clear the Market." The Bell Journal of Economics. Volume 14, Number 2. Autumn. pp. 562-572

Carlton, Dennis W. (1986) "The Rigidity of Prices." American Economic Review. Volume 76, Issue 4. September. Pp. 637-658. Reprinted in Sheshinski and Weiss (1993).

Cecchetti, Stephen G. (1986) "The Frequency of Price Adjustment: A Study of the Newsstand Prices of Magazines." Journal of Econometrics. Volume 31 p.255-274. Reprinted in Sheshinski and Weiss (1993).

Chain Store Age. (1950) Grocery Manager's edition. Lebhar-Friedman Publications. New York. June.

Consumer Reports. (2001) "Tissues disappear." December. p.63.

Dimand, Robert W. (2000). "Oskar Morgenstern on apparent price rigidity in the 1930s: a comment on Kovenock and Widdows." European Journal of Political Economy. Volume 16. pp.571-573. 
Food Marketing Institute. (1980) Supermarket Trends. Washington DC. Research Division, Food Marketing Institute.

Food Marketing Institute. (1981, 1982, 1985, 1986, 1994) Trends - Consumer Attitudes and the Supermarket. Washington DC. Research Division, Food Marketing Institute.

Goodwin, Barry K., Thomas J. Grennes, and Lee A. Craig. (2002) "Mechanical Refrigeration and the Integration of Perishable Commodity Markets." Explorations in Economic History. Volume 39. Number 2. April. Pp. 154-82.

Hall, Joseph B. (1957) "Evolution not Revolution: The Present Job of Management in Food Distribution." In The Tobe Lectures in Retail Distribution at the Harvard Business School. Second Series (1957-1958).

Hanes, Christopher. (1998) "Consistent Wholesale Price Series for the United States, 18601990." In Business Cycles Since 1820 ,Trevor J.O. Dick ed. Edward Elgar, Northampton, MA.

Hanes, Christopher. (1999) "Degrees of Processing and Changes in the Cyclical Behavior of Prices in the United States, 1869-1990." Journal of Money, Credit, and Banking. Volume 31, Number1. February. Pp. 35-53.

Hosken, Daniel, David Matsa, and David Reiffen. (2000). "How Do Retailers Adjust Prices?: Evidence from Store-Level Data." Federal Trade Commission Bureau of Economics Working Paper. January.

Kashyap, Anil K. (1995) "Sticky Prices: New Evidence from Retail Catalogs." Quarterly Journal of Economics. Pp. 245-274.

Koelln, Kenneth, and Mark Rush. (1993) "Rigid Prices and Flexible Products." Journal of Economics. Missouri Valley Economic Association. Volume 19. Number 1. Spring. Pp. 57-64.

Lal, Rajiv, and Carmen Matutes. (1994) "Retail Pricing and Advertising Strategies." Journal of Business. Volume 67, Issue 3. July. Pp. 345-370.

Lebhar, Godfrey M. (1963) Chain Stores in America: 1859-1962. Third Edition. Chain Store Publishing Corporation. New York.

Levy, Daniel, Mark Bergen, Shanantu Dutta, and Robert Venable. (1997) "The Magnitude of Menu Costs: Direct Evidence From Large U.S. Supermarket Chains." Quarterly Journal of Economics. August: Volume 112, Issue 3. Pp.791-825.

Levy, Daniel, and Andrew Young. (2004) " 'The Real Thing:' Nominal Price Rigidity of the Nickel Coke, 1886-1959." Journal of Money, Credit, and Banking. August. Volume 36, Number 4. pp. $765-799$

Mills, Frederick C., (1927) The Behavior of Prices. National Bureau of Economic Research. New York. 
Morgenstren, Oskar. (1931) "Free and fixed prices during the depression." Harvard Business Review. Volume 10. pp. 62-63

National Commission on Food Marketing, United States. (1966). Food from Farmer to Consumer. U.S. Government Printing Office. Washington.

Neilsen, A.C., Company $(1985,1989)$ Nielsen Annual Review of Retail Grocery Store Trends. Hackensack, NJ.

Nystrom, Paul H. (1919) Economics of Retailing. The Ronald press company. New York.

Nystrom, Paul H. (1930) Economics of Retailing. 3d ed. The Ronald press company. New York.

Pashigian, B. Peter. (1988) "Demand Uncertainty and Sales: A Study of Fashion and Markdown Pricing." American Economic Review. Volume 78, Issue 5. December pp.936-953.

Patten, Simon N. (1889) "The Stability of Prices." Publications of the American Economic Association. Volume III. Number 6. January.

Powers, Elizabeth T., and Nicholas J. Powers. (2001) "The Size and Frequency of Price Changes: Evidence from Grocery Stores." Review of Industrial Organization. Volume 18, Number 4. June 2001. Pp 397-416.

Schapker, Ben L. (1966) "Behavior Patterns of Supermarket Shoppers." Journal of Marketing. October. Pp.46-49.

Stigler, George J., and James K. Kindahl. (1973) "Industrial Prices, as Administered by Dr. Means." American Economic Review. Volume 63, Issue 4. Pp. 717-721.

Taylor, John B. (1999) "Staggered Price and Wage Setting in Macroeconomics." In Handbook of Macroeconomics Volume 1B. John B. Taylor and Michael Woodford Eds. Elsevier. Amsterdam.

Thompson, Gary D., and Paul N. Wilson (1999) "Market Demands for Bagged, Refrigerated Salads." Journal of Agricultural and Resource Economics. Volume 24. Number 2. December. Pp. 463-81.

United States Bureau of Labor Statistics. (various dates between 1911 and 1916) Retail Prices. Retail Prices and Cost of Living Series. BLS Bulletins 105, 106, 108, 110, 113, 115,125, $132,136,138$.

United States Department of Agriculture, Economic Research Service. (1966) Retail Prices of Selected Foods in Two North Carolina Areas, July 1962-June 1963.

Warner, Elizabeth J., and Robert B. Barsky. (1995) "The Timing and Magnitude of Retail Store Markdowns: Evidence from Weekends and Holidays." Quarterly Journal of Economics. Volume 110, Issue 2. May. Pp. 321-52.

Warren, G.F. and Pearson, F.A. Wholesale Prices for 213 Years, 1720 to 1932: Part I. Whole sale Prices in the United States for 135 Years, 1797 to 1932. Cornell University, Agricultural Experiment Station. Memoir 142. Ithaca, New York. 1932. 
Zbaracki, Mark J., Mark Ritson, Daniel Levy, Shantanu Dutta, and Mark Bergen. (2004) "Managerial and Customer Costs of Price Adjustment: Direct Evidence from Industrial Markets." Review of Economics and Statistics. Volume 86. Issue 2. May. pp. 514-33. 


\begin{tabular}{|c|c|c|c|c|}
\hline $\begin{array}{c}\text { Estimated Length } \\
\text { of Nominal } \\
\text { Rigidity }\end{array}$ & $\begin{array}{c}\text { Average } \\
\text { Absolute Size of } \\
\text { Change }\end{array}$ & $\begin{array}{l}\text { Period of } \\
\text { Coverage }\end{array}$ & Type of Good & Study \\
\hline 73 years & - & $1886-1959$ & Coca-Cola & $\begin{array}{c}\text { Levy and } \\
\text { Young (2004) }\end{array}$ \\
\hline 1.8 to 14 years & 14.3 to $29.4 \%$ & $1953-1979$ & $\begin{array}{l}\text { Magazine Cover } \\
\text { Prices }\end{array}$ & $\begin{array}{l}\text { Cecchetti } \\
\quad(1986)\end{array}$ \\
\hline 11.2 to 30 months & 5 to $17 \%$ & $1953-1987$ & $\begin{array}{l}\text { Catalog Apparel and } \\
\text { Outdoor Accessories }\end{array}$ & $\begin{array}{c}\text { Kashyap } \\
(1995)\end{array}$ \\
\hline 3.6 to 13.2 months & 0.8 to $7.7 \%$ & $1957-1966$ & $\begin{array}{l}\text { Wholesale Industrial } \\
\text { Prices }\end{array}$ & Carlton (1986) \\
\hline 4.3 months $^{36}$ & - & $1995-1997$ & Consumer Goods & $\begin{array}{c}\text { Bils and } \\
\text { Klenow (2002) }\end{array}$ \\
\hline $\begin{array}{l}3.0 \text { months }^{37} \\
2.7 \text { months } \\
2.5 \text { months } \\
2.0 \text { months }\end{array}$ & - & $\begin{array}{l}1791-1810 \\
1811-1830 \\
1821-1840 \\
1841-1860\end{array}$ & $\begin{array}{c}\text { Wholesale Prices in } \\
\text { Philadelphia }\end{array}$ & $\begin{array}{l}\text { Bezanson, et } \\
\text { al. (1936) }\end{array}$ \\
\hline $\begin{array}{l}2.8 \text { months }^{38} \\
2.6 \text { months } \\
3.2 \text { months } \\
2.1 \text { months } \\
1.9 \text { months }\end{array}$ & - & $\begin{array}{l}1890-1897 \\
1898-1905 \\
1906-1913 \\
1914-1921 \\
1922-1925\end{array}$ & $\begin{array}{c}\text { Wholesale Commodity } \\
\text { Prices }\end{array}$ & Mills (1927) \\
\hline 4.5 to 15 weeks & - & 1991-1992 & $\begin{array}{c}\text { Prices in Supermarket } \\
\text { chains }\end{array}$ & $\begin{array}{l}\text { Levy, et al. } \\
\quad(1997)\end{array}$ \\
\hline 2.3 weeks & $24 \%$ & 1986-1992 & $\begin{array}{l}\text { Lettuce in grocery } \\
\text { stores }\end{array}$ & $\begin{array}{c}\text { Powers and } \\
\text { Powers (2001) }\end{array}$ \\
\hline
\end{tabular}

${ }^{36}$ Median length

${ }^{37}$ Approximated from Bezanson, et al. (1936) chart VI p. 55.

${ }^{38}$ Inverse of median commodity frequency of price change from appendix table VIII. 


\begin{tabular}{lcc}
\hline \multicolumn{2}{c}{ Table 2. A Comparison of Selected Fundamentals in the Three Periods } \\
\hline & $\begin{array}{c}\text { June 1889 } \\
\text { September 1891 }\end{array}$ & $\begin{array}{c}\text { June 1997- } \\
\text { September 1999 }\end{array}$ \\
$\begin{array}{l}\text { Average Annual Wholesale Price Inflation } \\
\text { Rate }^{39}\end{array}$ & $0.00 \%$ & $0.28 \%$ \\
Nearby or Included Business Cycle Dates $^{40}$ & $\begin{array}{c}\text { April 1888 Trough } \\
\text { July 1890 Peak } \\
\text { May 1891 Trough } \\
\text { January 1893 Peak }\end{array}$ & $\begin{array}{c}\text { March 1991 Trough } \\
\text { March 2001 Peak }\end{array}$ \\
Interest rate $^{41}$ & $4.57 \%$ & $6.79 \%$ \\
\hline
\end{tabular}

\begin{tabular}{lll}
\hline & \multicolumn{2}{c}{ Table 3. 48 Products Are Available in 1889-1891 and 1997-1999 } \\
\hline Food Goods & $\begin{array}{l}\text { Household goods, furniture, } \\
\text { and hardware }\end{array}$ & Clothing \\
& 1. Laundry Starch & 1. Men's underwear \\
1. Beef Roasts & 2. Cleaning Products & 2. Men's Socks \\
2. Ham & 3. Stoves and ovens & 3. Men's shirts \\
3. Eggs & 4. Kitchen table, chair and sets & 4. Women's pantyhose and stockings \\
4. Bacon & 5. Dining room furniture & 5. Waterproof Footwear \\
5. Sugar & 6. Bedroom furniture & 6. Men's work shoes and boots \\
6. Butter and Margarine & 7. Drinking Glasses & 7. Women's dress and casual shoes \\
7. Potatoes & 8. Knives and Forks & \\
8. Milk & 9. Kitchen Knives & \\
9. Flour & 10. Dishes & \\
10. Lard & 11. Nonelectric cookingware & \\
11. Cornmeal & 12. Shovels & \\
12. Mutton & 13. Rope & \\
13. Bread & 14. Saws, axes, and hammers & \\
14. Turkey (excluding canned) & & \\
15. Tomatoes & & \\
16. Canned Fruit & & \\
17. Salt and other seasonings & & \\
18. Beer & & \\
19. Rice & & \\
20. Canned Fish & & \\
21. Cheese & & \\
22. Coffee & & \\
23. Tea & & \\
24. Dried Beans & & \\
25. Dried Fruits & & \\
26. Fresh Vegetables & & \\
27. Canned vegetables & & \\
\hline
\end{tabular}

${ }^{39}$ 1889-1891 from Warren and Pearson (1932), Table 1. 1997-1999 from Bureau of Labor Statistics, Producer Price Index, All Commodities.

${ }^{40}$ NBER (http://www.nber.org/cycles.html)

${ }^{41}$ Moody's AAA Corporate Bond Yield. Calculated as geometric mean of closing yield on last day of month. Data from Global Financial Data (www.globalfindata.com). 


\begin{tabular}{|c|c|c|}
\hline & $\begin{array}{c}\text { June } 1889- \\
\text { September } 1891\end{array}$ & $\begin{array}{r}\text { June } 1997- \\
\text { September } 1999\end{array}$ \\
\hline Total Number of First Differences & 45,683 & 40,474 \\
\hline Number of Price Changes & 2,367 & 12,709 \\
\hline Average Number of First Differences per Month & 1,692 & 1,499 \\
\hline $\begin{array}{l}\text { Average Observed Consecutive First Differences } \\
\text { (maximum 27) }\end{array}$ & 24.5 & 9.9 \\
\hline $\begin{array}{l}\text { Average Number of First Differences per Product Group in } \\
\text { a Location }\end{array}$ & 246.9 & 238.1 \\
\hline Share of First-Differences that are Food Goods & $54 \%$ & $83 \%$ \\
\hline $\begin{array}{l}\text { Unweighted Average Absolute Size of Non-zero First } \\
\text { Differences of Log Price }\end{array}$ & $16.1 \%$ & $24.9 \%$ \\
\hline $\begin{array}{l}\text { Unweighted Average of the Annualized First Difference of } \\
\text { Log Price }\end{array}$ & $0.07 \%$ & $-0.93 \%$ \\
\hline Share of Price Changes that are Price Increases & 52.8 & 52.2 \\
\hline
\end{tabular}




\begin{tabular}{|c|c|c|}
\hline & $\begin{array}{l}\text { June } 1889- \\
\text { September } 1891\end{array}$ & $\begin{array}{l}\text { June } 1997- \\
\text { September } 1999\end{array}$ \\
\hline \multicolumn{3}{|c|}{ Frequency of Price Changes (Share of Goods Changing Price Each Month) } \\
\hline Unfiltered data & $5.2 \%$ & $31.4 \%$ \\
\hline 1-Month Temporary Price Reductions Filtered Out & $4.8 \%$ & $22.4 \%$ \\
\hline 2-Month Temporary Price Reductions Filtered Out & $4.4 \%$ & $18.9 \%$ \\
\hline $\begin{array}{l}\text { Price Markdowns and 1-Month Temporary Price } \\
\text { Reductions Filtered Out }\end{array}$ & $4.6 \%$ & $22.1 \%$ \\
\hline $\begin{array}{l}\text { Price Markdowns and 2-Month Temporary Price } \\
\text { Reductions Filtered Out }\end{array}$ & $4.3 \%$ & $18.7 \%$ \\
\hline Magnitude of Price Changes & & \\
\hline Unfiltered data & $16.1 \%$ & $24.9 \%$ \\
\hline 1-Month Temporary Price Reductions Filtered Out & $16.3 \%$ & $22.9 \%$ \\
\hline 2-Month Temporary Price Reductions Filtered Out & $16.1 \%$ & $22.0 \%$ \\
\hline $\begin{array}{l}\text { Price Markdowns and 1-Month Temporary Price } \\
\text { Reductions Filtered Out }\end{array}$ & $16.4 \%$ & $22.9 \%$ \\
\hline $\begin{array}{l}\text { Price Markdowns and 2-Month Temporary Price } \\
\text { Reductions Filtered Out }\end{array}$ & $16.3 \%$ & $22.1 \%$ \\
\hline
\end{tabular}




\begin{tabular}{|c|c|c|}
\hline \multicolumn{3}{|c|}{$\begin{array}{c}\text { Table 6. The Next Price Change was less likely to be the Same Sign in 1997-1999 } \\
\text { Compared to } 1889-1891\end{array}$} \\
\hline & $\begin{array}{c}\text { June } 1889- \\
\text { September } 1891\end{array}$ & $\begin{array}{c}\text { June } 1997- \\
\text { September } 1999\end{array}$ \\
\hline $\begin{array}{l}\text { Number of Price Changes: } \\
\text { Increase and previous price change was increase }\end{array}$ & 464 & 1513 \\
\hline Decrease and previous price change was increase & 480 & 3514 \\
\hline Increase and previous price change was decrease & 479 & 3839 \\
\hline Decrease and previous price change was decrease & 895 & 4642 \\
\hline $\begin{array}{l}\text { Probabilities (shares): } \\
\text { Next price change in same direction as previous } \\
\text { price change }\end{array}$ & $58.6 \%$ & $45.6 \%$ \\
\hline $\begin{array}{l}\text { Next price change is an increase given previous } \\
\text { price change was an increase }\end{array}$ & $49.2 \%$ & $30.1 \%$ \\
\hline $\begin{array}{l}\text { Next price change is a decrease given previous } \\
\text { price change was a decrease }\end{array}$ & $65.1 \%$ & $54.7 \%$ \\
\hline
\end{tabular}


Figure 1A. Frequency of Price Changes by Product

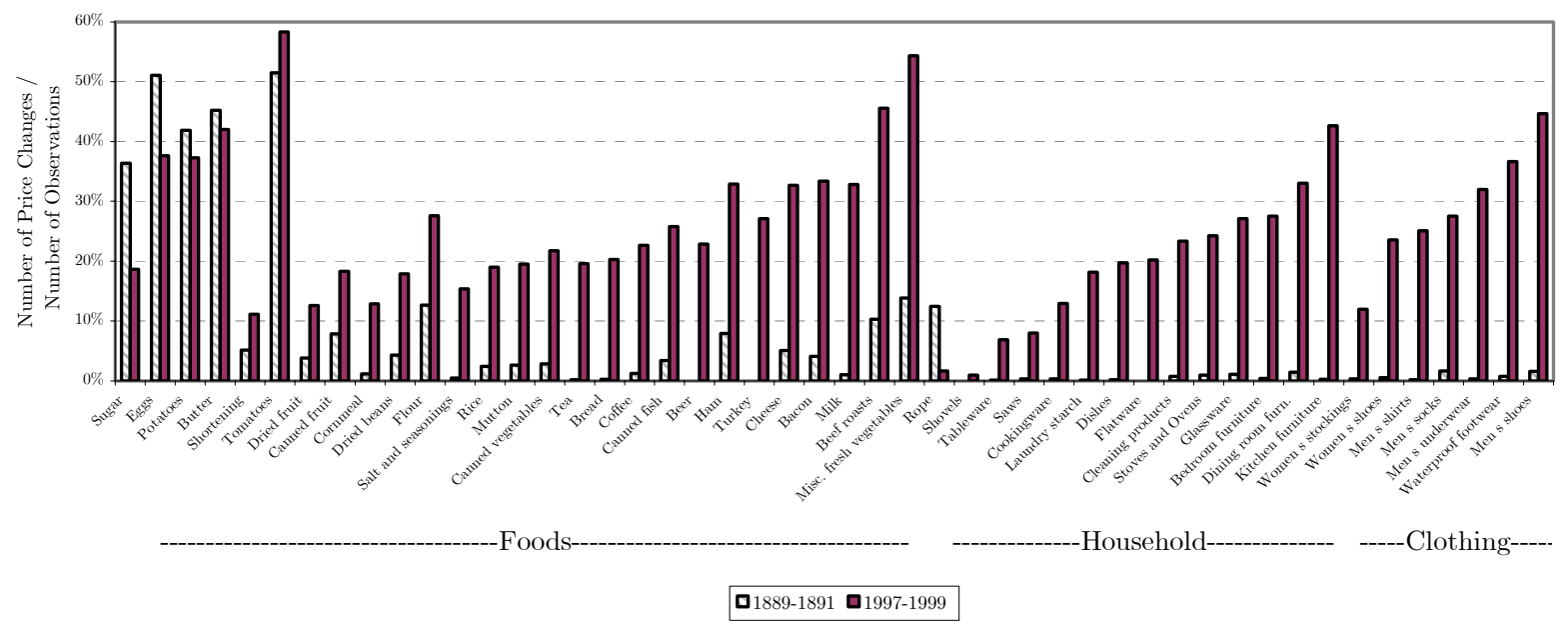

Figure 1B. Frequency of Price Changes by Location

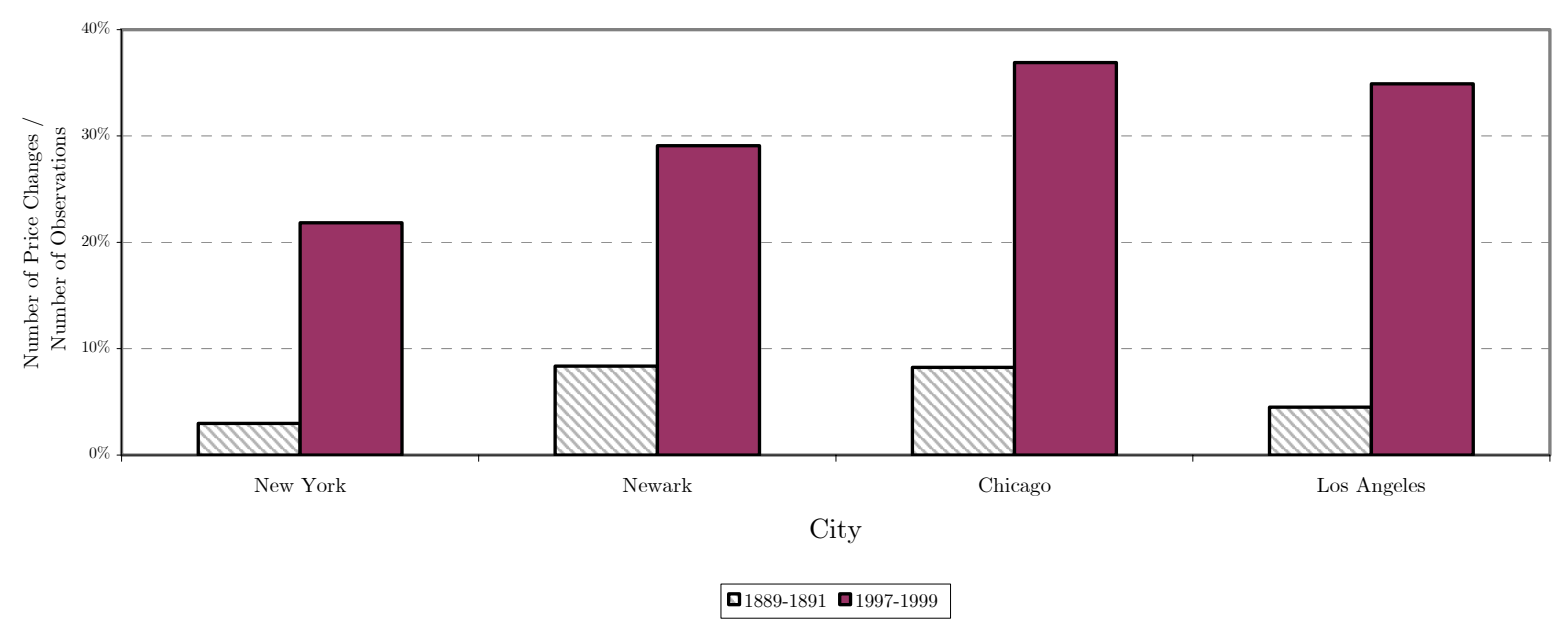

Figure 1C. Frequency of Price Changes by Month

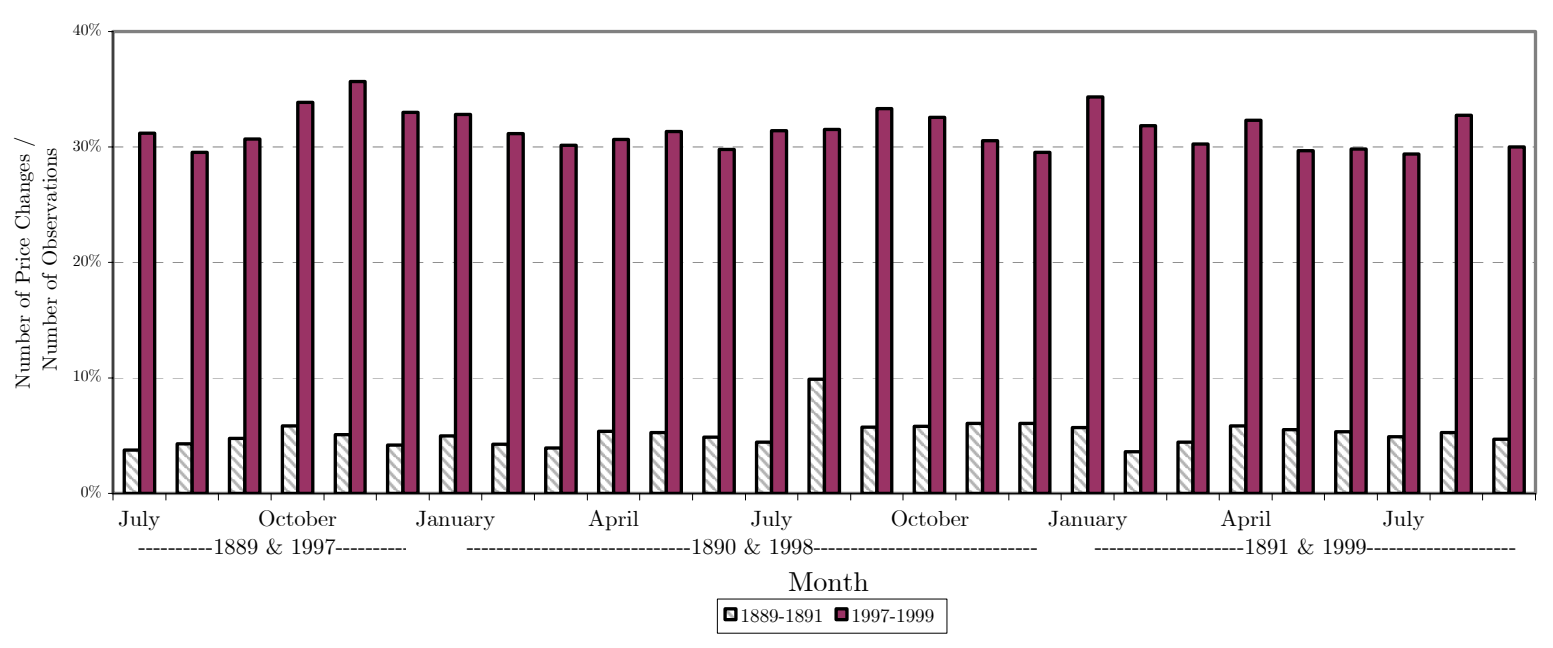


Figure 2. The Probability of a Price Remaining Unchanged is Higher in 1889-1891 (Kaplan-Meier Survival Function - All Observations - Unweighted)

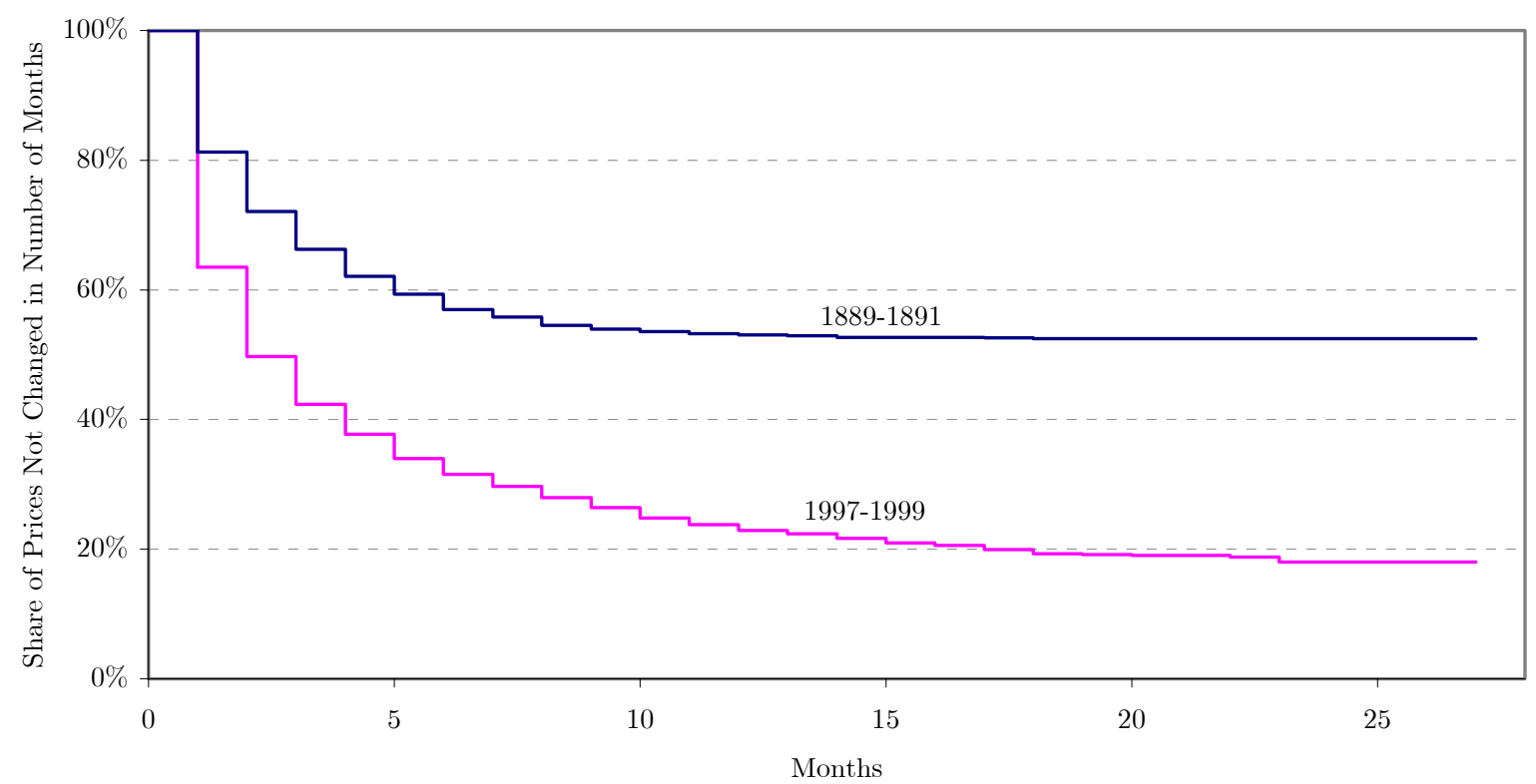


Figure 3A. Magnitude of Price Changes by Product

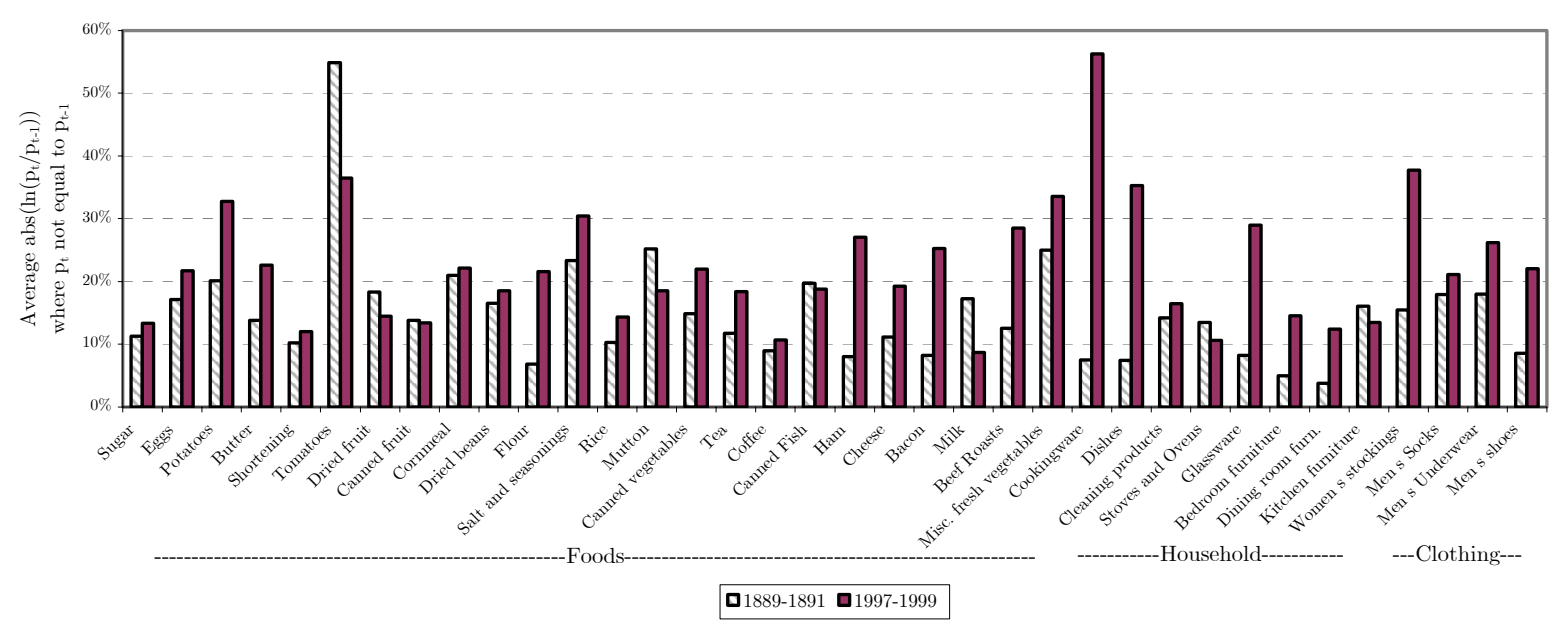

Figure 3B. Magnitude of Price Changes by Location

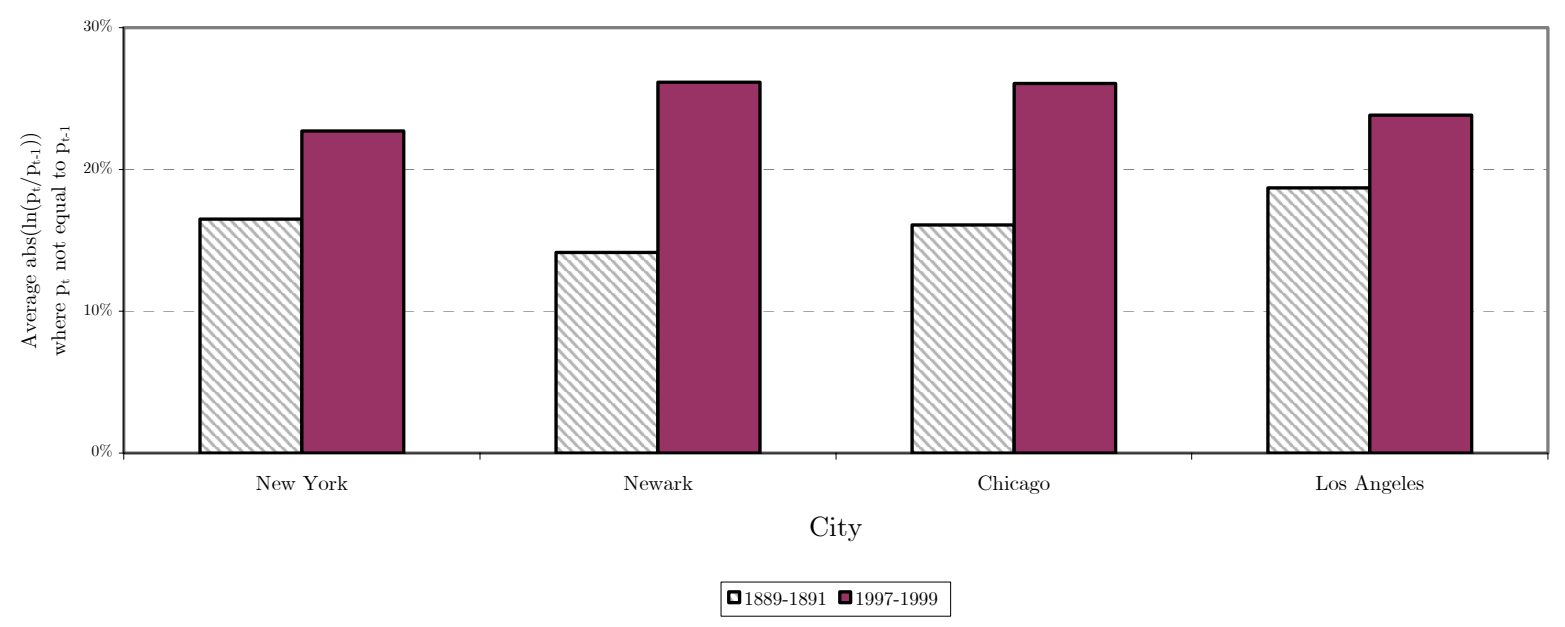

Figure 3C. Magnitude of Price Changes by Month

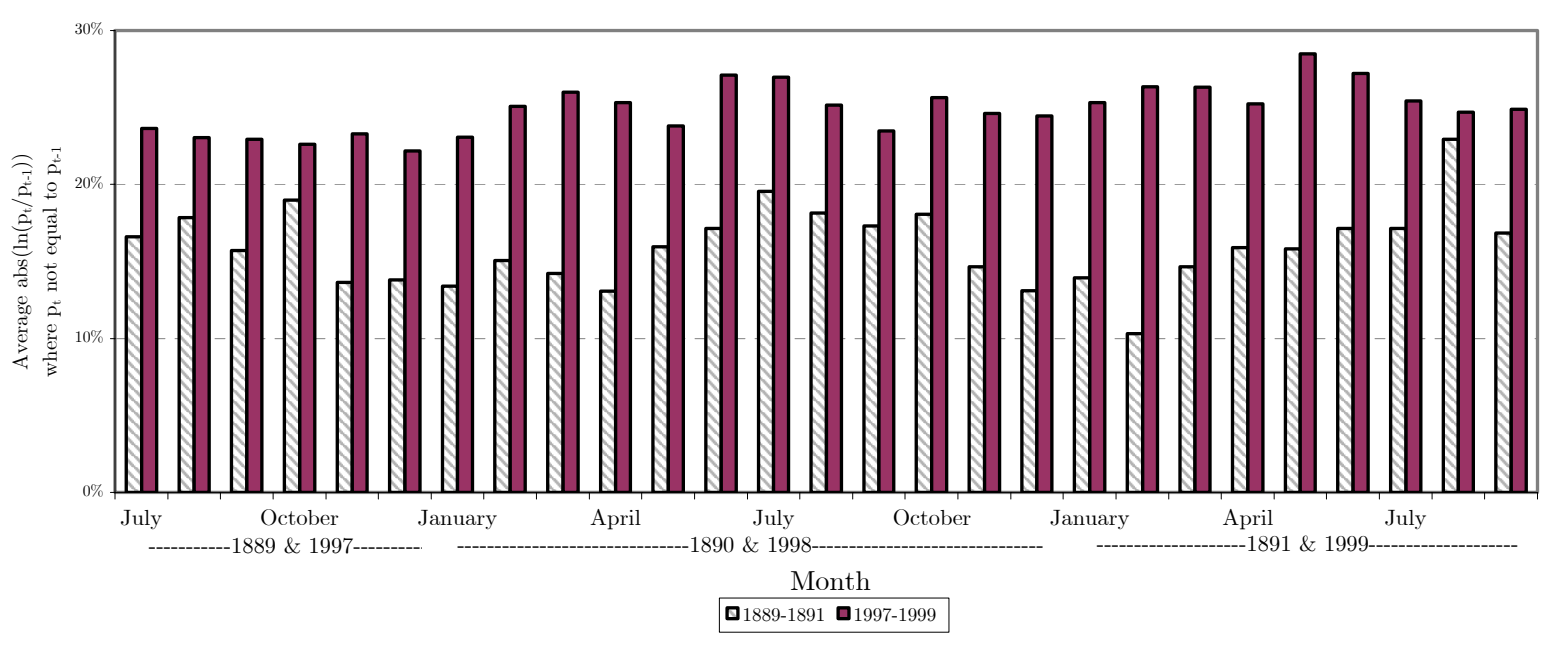


Figure 4. Frequency vs. Magnitude of Price Changes in 1889-1891

by Location-Product Group

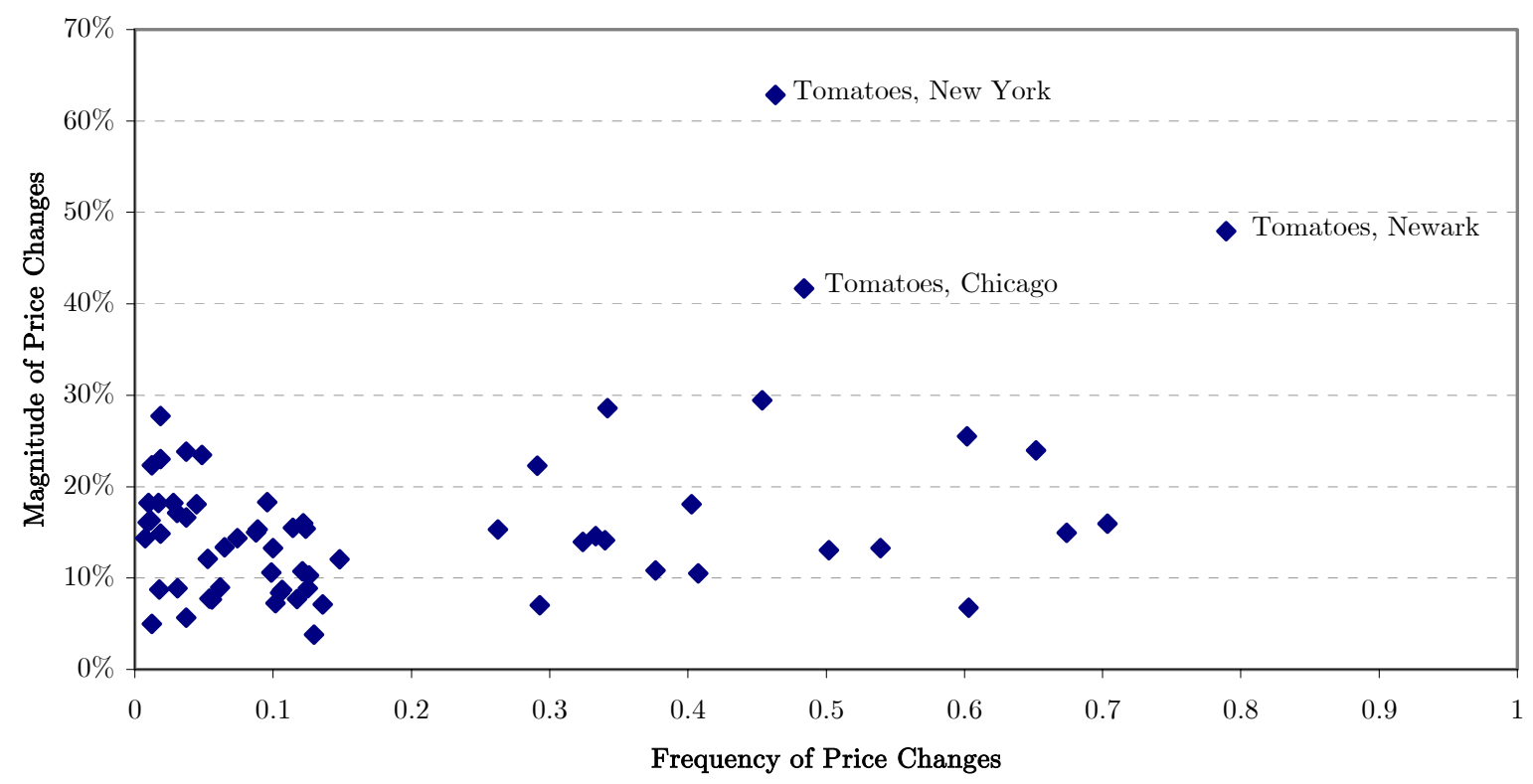

Figure 5. Frequency vs. Magnitude of Price Changes in 1997-1999

by Location-Product Group

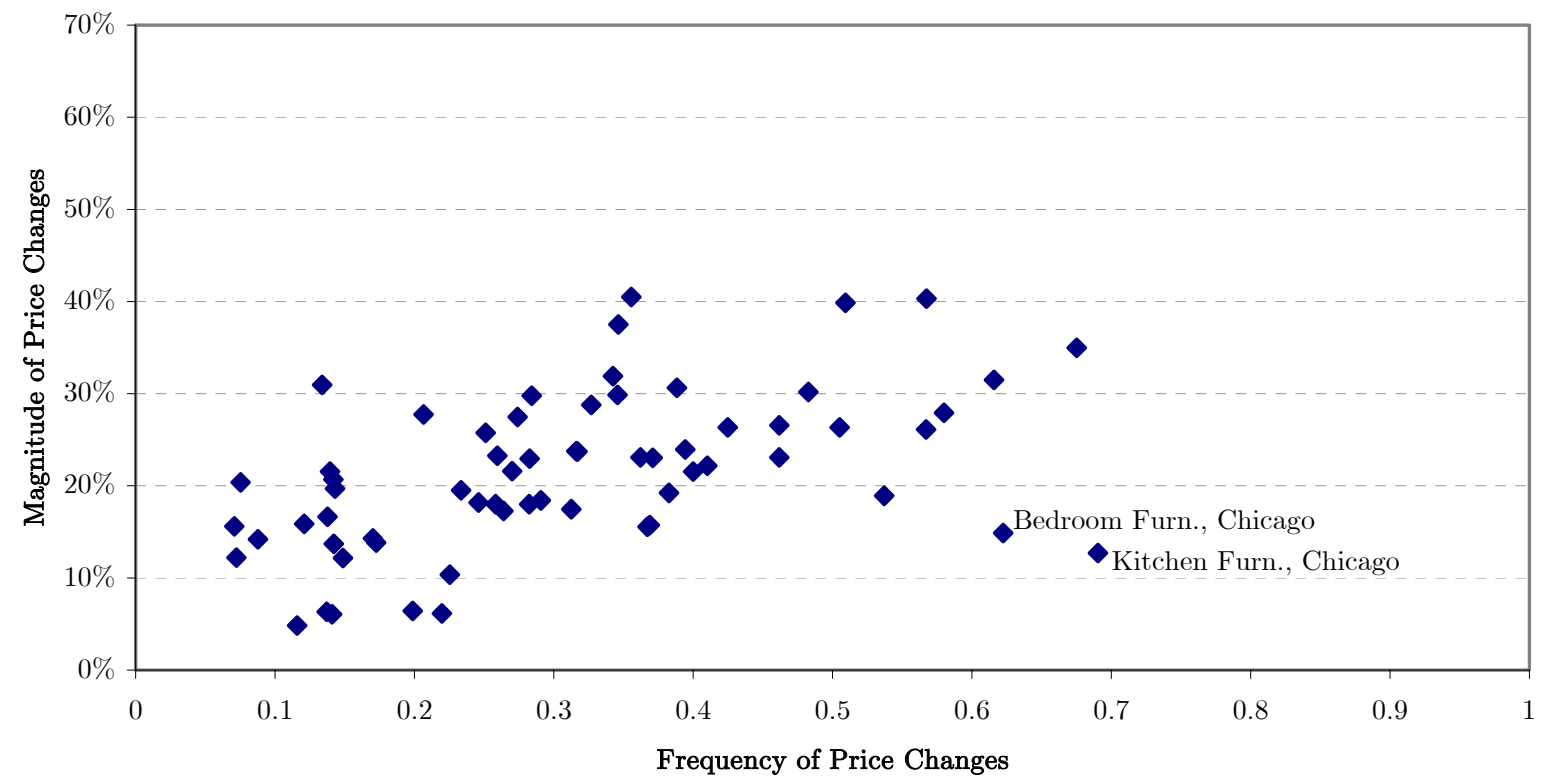


Figure 6. Cumulative Distribution of Size of Price Changes

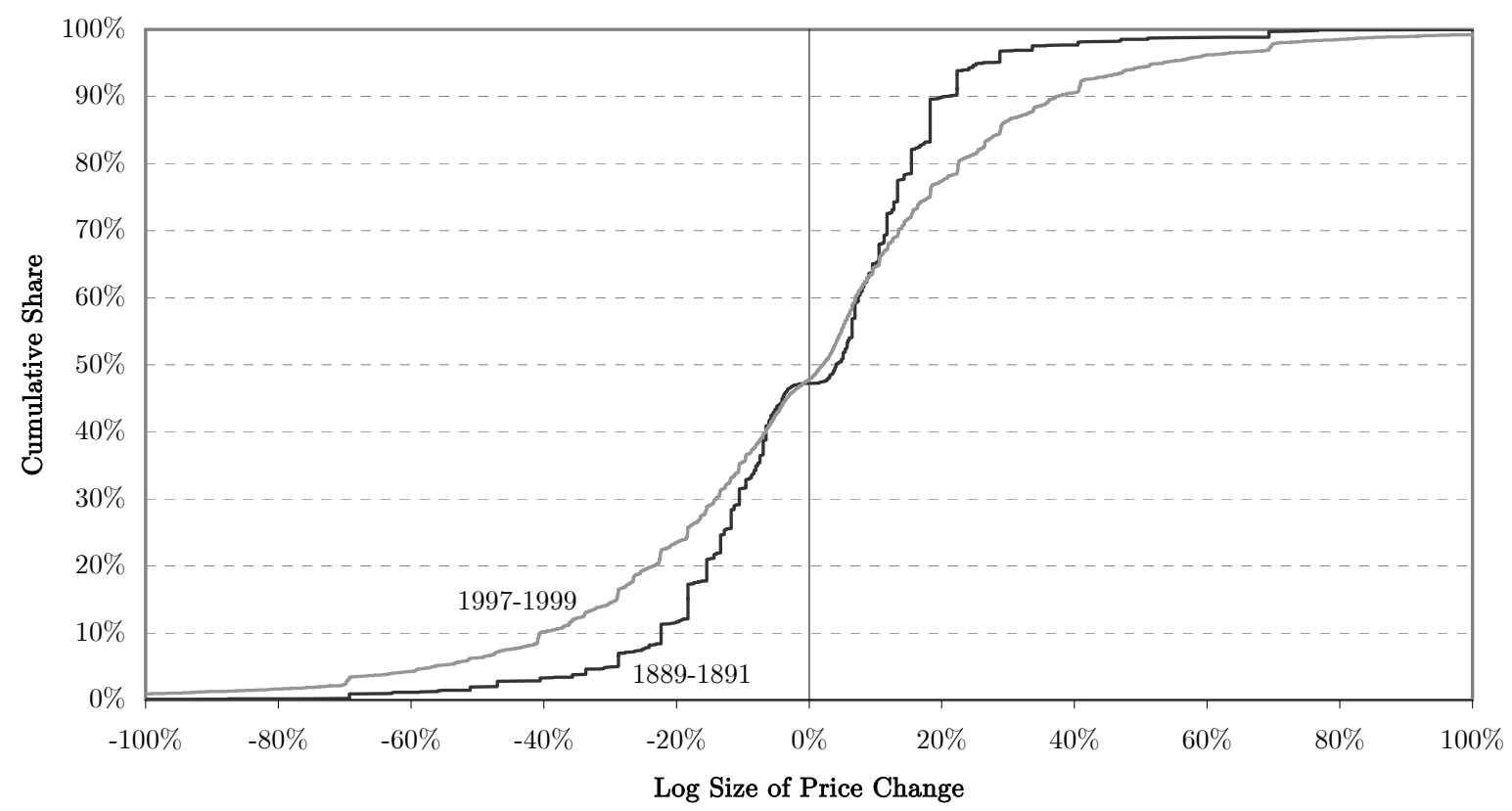

Figure 7. Small Price Changes Were Less Common in 1889-1891

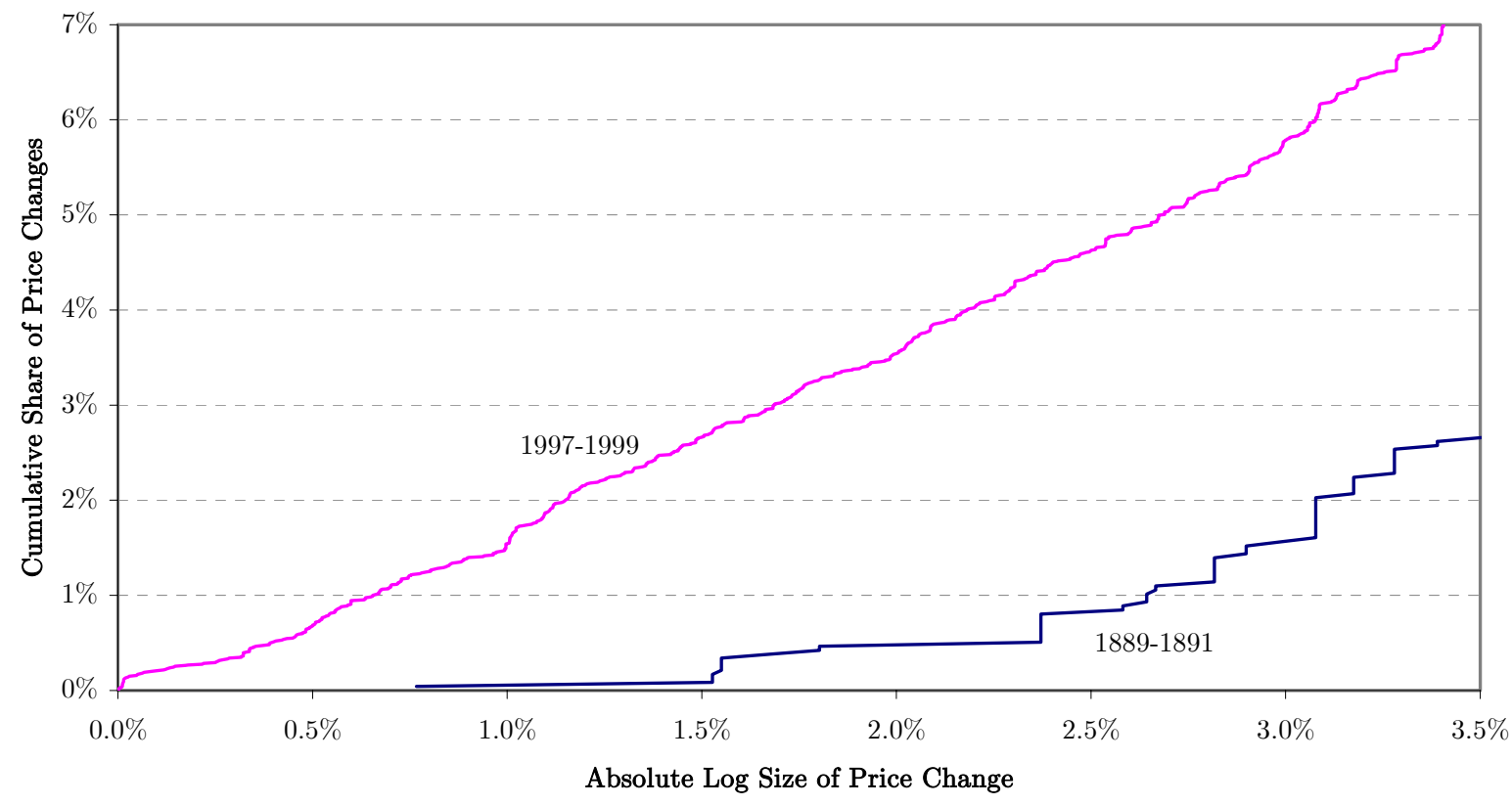


Figure 8. The Size of Grocery Stores Increased Over Time

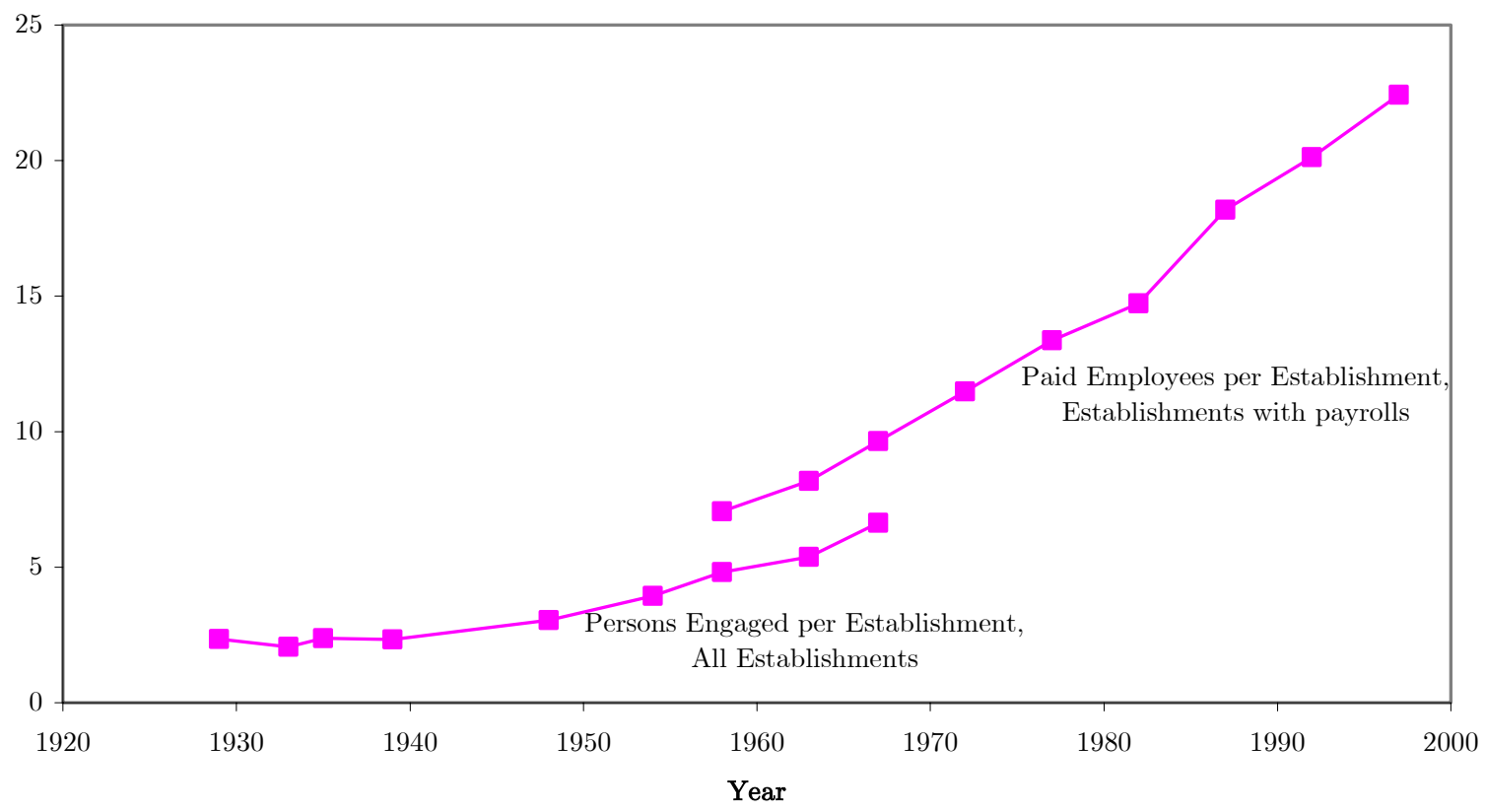

Sources: Historical Statistics of the United States, Colonial Times to 1970 series T95 and T97. Statistical Abstract of the United States 1963, 1968, 1972, 1977, 1982, 1985. US Bureau of the Census, Economic Census 1987, 1992, 1997.

Figure 9.

The Size of Price Changes in a Simple Time Dependent Example

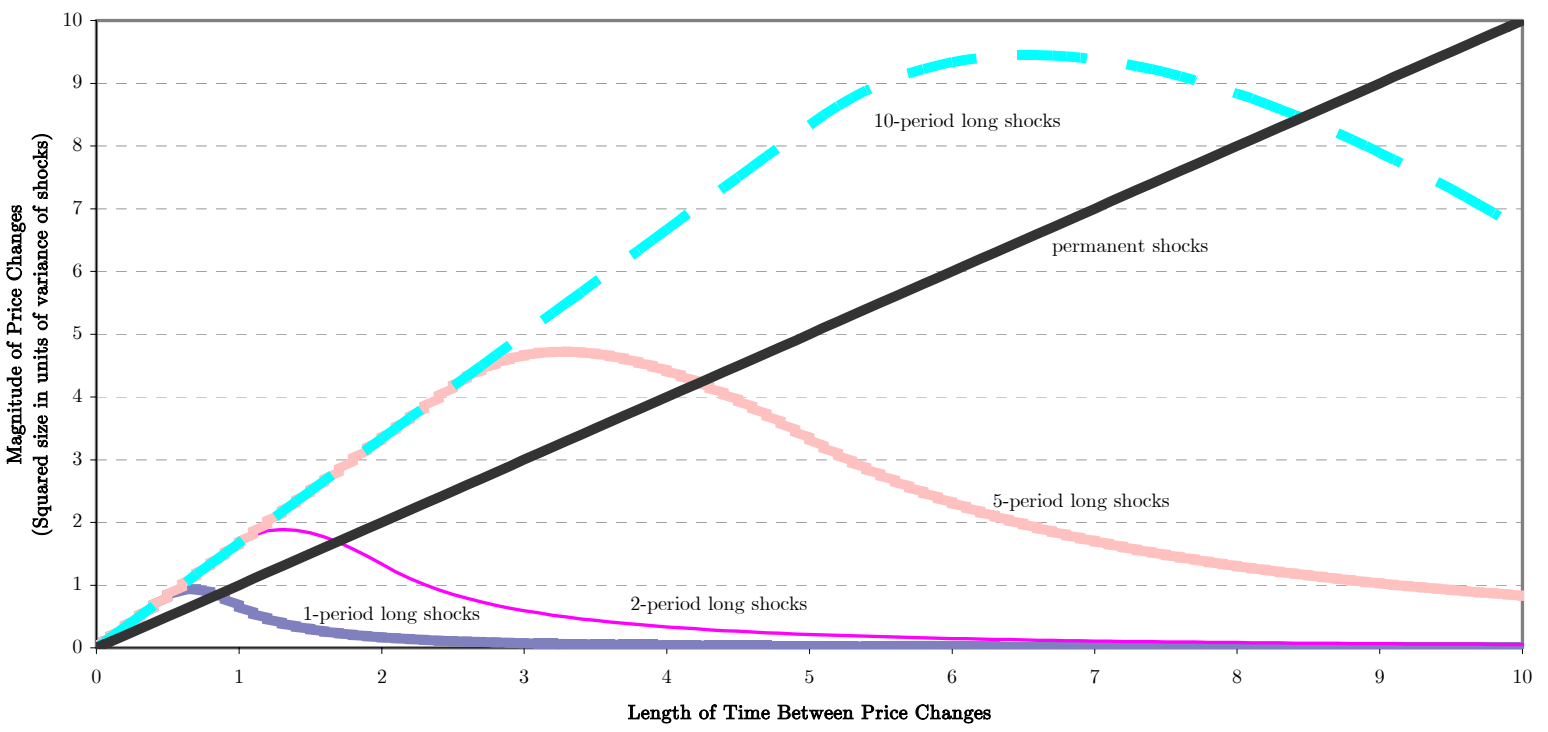




\section{Data Appendix}

To my knowledge there are only four sources for historical monthly time-series of retail price microdata for the United States. ${ }^{42}$ The four sources are: 1. The Aldrich report (Aldrich, 1892) covering data from June 1889 to September 1891; 2. Various Bureau of Labor Statistics bulletins (United States Bureau of Labor Statistics, various dates) covering retail prices of 12 to 18 foods in a number of cities from 1911 to 1916; 3. Retail Prices of Selected Foods in Two North Carolina Cities, July 1962 to June 1963 (USDA, 1966); and, 4. The underlying data from the Consumer Price Index (CPI) since the mid-1980s, which is available only by special arrangement at the BLS office in Washington DC. The North Carolina food prices for 19621963 were not used in this study, because the cities covered are not sampled monthly in either the Aldrich report or the CPI. The 1911-1916 BLS data is also not used because the number of goods covered is much smaller than either Aldrich report or the CPI sample, and the macroeconomic conditions (i.e. higher inflation and war starting in 1914) differed from the other two periods.

The microdata for 1889-1891 is extracted from exhibits appended to the Aldrich report [Aldrich (1892)], an exhaustive study of retail and wholesale prices conducted by the then recently formed Bureau of Labor Statistics under the direction of the Senate Finance committee. The Aldrich Report was one of the first official attempts by an office of the government to determine the course of prices and wages in the United States. Quoting approximately 115 products in each of 70 cities for 28 months, the breadth of coverage in Aldrich report would not be matched by regular BLS sampling for at least 30 years.

After the Aldrich report regular BLS sampling of retail prices did not begin until 1903, and even then comprised only food goods until 1917. ${ }^{43}$ Through a large number of pre-WWII revisions and major post-war revisions in 1953, 1964, 1978, 1987, and 1998 the current consumer price index evolved. Even with large changes in the product mix of the consumer's basket over the last one hundred and ten years, and enormous shifts in population distribution, some of the goods and cities sampled in the Aldrich Report overlap with the sampling for today's Consumer Price Index.

\footnotetext{
${ }^{42}$ It should be noted that there has been some innovative work in reconstructing time series of prices (for examplem magazine cover prices (Cecchetti, 1986) and catalog prices (Kashyap, 1995)). While a potentially longer time span of prices may be obtained this way, these sources are much more constrained in the frequency of quotes, the number of goods covered. Further, the data can not be used to compare differences across cities.

${ }^{43}$ BLS Bulletin No. 699.
} 
A series of interactions between the author and BLS personnel led to the formation a list of goods and cities roughly comparable with the two different groups of data. This concordance is given as Appendix Tables A1 and A2. After compilation of the data specifications, and a required petition to the Commissioner of the BLS, the BLS provided screened 1997-1999 microdata for comparison with the Aldrich Report data.

In tailoring the 1997-1999 data to conform as closely as possible to the available data from 1889-1891, beginning and ending dates were chosen to exactly match the length and seasonality of the earlier data. Both sets of data begin in June and end 27 months later in September. Products were chosen to maximize the number of comparable product groups common to both samples. Localities were chosen to maximize the number of localities with monthly sampling in both periods.

As I use microdata rather than a price index, the various CPI formula changes over the years are not relevant and will not affect the results. The data in both periods were sampled by trained BLS personnel bringing, hopefully, some degree of professionalism and uniformity to the physical sampling, though the statistical techniques of determining what should be sampled have changed tremendously over the time period. One change between the periods is the disappearance of routine merchandise delivery by 1997-1999. Appendix Table A3 displays additional methodological comparisons of the two periods.

One note of caution should be added. Both the geographic and product group definitions are somewhat more inclusive in 1997-1999 than in the earlier period. For example, the Aldrich Report sampled white beans. The narrowest available comparable product category in the current data (a cluster within an entry level item) contains all dried beans, peas, and lentils. Similarly, the 1889-1891 data sample Newark, New Jersey. The closest comparable locality for the 1997-1999 dataset includes not only Essex county (where Newark is located) but also the counties of Bergen, Hudson, Hunterdon, Mercer, Middlesex, Monmouth, Morris, Ocean, Passaic, Somerset, Sussex, Union, Warren, as well as the county of Pike, Pennsylvania. More comparisons between the 1889-1891 and the 1997-1999 groupings can be seen in Appendix Tables A1 and A2. Given the increasing mobility of the population it is assumed the broader groupings do not substantially alter the results. 
Table A1. Geographical Correspondence Between 1889-1891 and 1997-1999

\section{9-1891 City Classification Current BLS Region Classification}

1. Los Angeles, CA

2. Chicago, IL

Los Angeles-Long-Beach, CA PMSA (A419)

Chicago-Gary-Kenosha, IL-IN-WI CMSA

(Cook, DeKalb (starting 1998), DuPage, Grundy, Kane,

Kankakee (starting 1998), Kendall, Lake, McHenry, and Will

counties in Illinois; Lake and Porter counties in Indiana; and

Kenosha county in Wisconsin) (A207)

3. New York, NY

New York City

(Bronx, Kings, New York, Queens, Richmond counties) (A109)

4. Newark, NJ

New Jersey-Pennsylvania suburbs

(Bergen, Essex, Hudson, Hunterdon, Mercer (starting 1998),

Middlesex, Monmouth, Morris, Ocean, Passiac, Somerset, Sussex,

Union and Warren (starting 1998) counties in New Jersey; and

Pike county in Pennsylvania (starting 1998))(A111) 
Table A2. Product Correspondence Between 1889-1891 and 1997-1999

Food

1889-1891 Product

F1. Flour, rye.

Flour, wheat, best Minnesota or similar grade

F2. Rice, Carolina prime or similar grade

F3. Meal, corn

F4. Bread, best quality of bakers'

F5. Meat, bacon

F6. Meat, ham

F7. Meat, beef, roasting cuts of.

F8. Meat, mutton, shoulders

F9. Meat, turkey, dressed

F10. Fish, oysters, canned, Baltimore standard, No. 1 size

Fish, salmon, canned, Columbia River, No. 1 size

Fish, salmon, canned, red Alaska, No. 1 size

F11. Eggs, domestic, not limed, and from the vicinity of the place of quotation

F12. Milk, fresh

F13. Cheese, best factory

F14. Vegetables, fresh, potatoes, the quality of white domestic in most use

F15. Vegetables, fresh, tomatoes, from the vicinity of place of quotation.

F16. Vegetables, fresh, onions, white, from the vicinity of place of quotation.

Vegetables, fresh, cabbage, from the vicinity of place of quotation.

Vegetables, fresh, turnips, from the vicinity of place of quotation.

F17. Vegetables, canned, corn,
1987 CPI Revision Product 1997 CPI Revision

Category (ELI)

Flour (01011)

Product Category (ELI)

Flour (FA011 cluster 1)

Rice (01031)

Rice (FA031 cluster 1)

Cornmeal (01032 cluster 2b)

Cornmeal (FA031 cluster 3)

Bread other than white (02021)

White bread (02011)

Bacon (04011)

Ham (excluding canned)

(04031)

Chuck roast (03021)

Round roast (03031)

Lamb and mutton (05014

cluster 1b)

Turkey excluding canned

(06031 cluster 2b)

Canned fish or seafood

(07011)

Bread (FB011 both clusters)

Bacon and related products

(FD011 cluster 1)

Ham (excluding canned)

(FD021 cluster 1)

Uncooked beef roasts

(FC021 all clusters)

Lamb and mutton (FE013

cluster 1)

Turkey excluding canned

(FF021 cluster 1)

Canned fish or seafood

(FG021 cluster 1)
Eggs in Shell (08011 cluster 1c)

Fresh whole milk (09011)

Cheese (10021)

Potatoes (12011)

Tomatoes (12031)

Tomatoes (FL031)

Other fresh vegetables

(12041)

Other fresh vegetables

(FL041 cluster 1)

Eggs in shell (FH011 cluster 1)

Fresh Whole Milk (FJ011

cluster 1)

Cheese and related products

(FJ021)

Potatoes (FL011)

Canned cut corn (14022)

Canned vegetables (FM011 


\begin{tabular}{|c|c|c|c|}
\hline & $\begin{array}{l}\text { standard, No. } 2 \text { size. } \\
\text { Vegetables, canned, pease, } \\
\text { standard, No. } 2 \text { size. } \\
\text { Vegetables, canned, tomatoes, } \\
\text { standard, No. } 3 \text { size. }\end{array}$ & $\begin{array}{l}\text { Canned tomatoes and tomato } \\
\text { juice (14023 cluster } 2 \mathrm{~b}) \\
\text { Other canned vegetables and } \\
\text { vegetable juices (14023 cluster } \\
4 \mathrm{~b})\end{array}$ & cluster 2) \\
\hline F18. & Beans, white medium, best & $\begin{array}{l}\text { Dried beans (14023 cluster } \\
\text { 3b) }\end{array}$ & $\begin{array}{l}\text { Dried beans, peas, and } \\
\text { lentils (FM031 cluster 2) }\end{array}$ \\
\hline F19. & $\begin{array}{l}\text { Fruit, peaches, canned, No. } 3 \\
\text { size, standard. }\end{array}$ & $\begin{array}{l}\text { Canned Fruit (13031 cluster } \\
\text { 1b) }\end{array}$ & $\begin{array}{l}\text { Canned Fruit (FM011 } \\
\text { cluster 1) }\end{array}$ \\
\hline F20. & $\begin{array}{l}\text { Fruit, prunes, California. } \\
\text { Fruit, prunes, Turkish. } \\
\text { Fruit, raisins, California, medium } \\
\text { quality. } \\
\text { Fruit, raisins, Valencia. } \\
\text { Fruit, currants, Zante. } \\
\text { Fruit, apples, dried, good quality, } \\
\text { evaporated. }\end{array}$ & Dried fruit (13031 cluster $2 \mathrm{~b}$ ) & $\begin{array}{l}\text { Dried and processed fruit } \\
\text { (FM031 cluster 1) }\end{array}$ \\
\hline F21. & Coffee, Rio, fair, nonroasted & $\begin{array}{l}\text { Roasted Coffee (17031) } \\
\text { Instant and Freeze Dried } \\
\text { Coffee }(17032)\end{array}$ & $\begin{array}{l}\text { Coffee (FP011) (both } \\
\text { clusters) }\end{array}$ \\
\hline F22. & $\begin{array}{l}\text { Tea, Japan, medium grade. } \\
\text { Tea, Oolong, medium grade. }\end{array}$ & Tea $(17052)$ & Tea (FP021) \\
\hline F23. & Sugar, standard granulated. & $\begin{array}{l}\text { Sugar and artificial } \\
\text { sweeteners (15021) }\end{array}$ & $\begin{array}{l}\text { Sugar and artificial } \\
\text { sweeteners (FR011) }\end{array}$ \\
\hline F24. & $\begin{array}{l}\text { Oleomargarine } \\
\text { Butter, best creamery, excluding } \\
\text { fancy grade } \\
\text { Butter, best dairy, excluding } \\
\text { fancy grade }\end{array}$ & $\begin{array}{l}\text { Margarine (16011) } \\
\text { Butter (10011) }\end{array}$ & $\begin{array}{l}\text { Margarine (FS011 cluster 2) } \\
\text { Butter (FS011 cluster 1) }\end{array}$ \\
\hline F25. & $\begin{array}{l}\text { Lard, compound } \\
\text { Lard, pure leaf }\end{array}$ & $\begin{array}{l}\text { Lard and shortening (16012 } \\
\text { cluster 1a) }\end{array}$ & $\begin{array}{l}\text { Lard and shortening (FS032 } \\
\text { cluster 1) }\end{array}$ \\
\hline F26. & $\begin{array}{l}\text { Salt, domestic, common fine. } \\
\text { Salt, imported, best dairy. } \\
\text { Spices, mustard, best domestic. } \\
\text { Spices, nutmegs. No. } 1 . \\
\text { Spices, pepper, whole Singapore. }\end{array}$ & $\begin{array}{l}\text { Salt and other seasonings and } \\
\text { spices (18041) }\end{array}$ & $\begin{array}{l}\text { Salt and other seasonings } \\
\text { and spices (FT041) }\end{array}$ \\
\hline F27. & Beer & $\begin{array}{l}\text { Beer, ale, and other malt } \\
\text { beverages at home (20011) }\end{array}$ & $\begin{array}{l}\text { Beer, ale, and other malt } \\
\text { beverages at home (FW011) }\end{array}$ \\
\hline \multicolumn{4}{|c|}{ Household goods, furniture, and hardware } \\
\hline & 1889-1891 Product & $\begin{array}{l}1987 \text { CPI Revision Product } \\
\text { Category (ELI) }\end{array}$ & $\begin{array}{l}1997 \text { CPI Revision } \\
\text { Product Category }\end{array}$ \\
\hline H1. & Starch, ordinary laundry. & $\begin{array}{l}\text { Laundry products ( } 33012 \\
\quad \text { cluster 1) }\end{array}$ & $\begin{array}{l}\text { Laundry Products other } \\
\text { than soaps and } \\
\text { detergents (HN011 } \\
\text { cluster } 2)\end{array}$ \\
\hline $\mathrm{H} 2$. & Ammonia, household. & $\begin{array}{l}\text { Cleaning products ( } 33012 \\
\quad \text { cluster 2) }\end{array}$ & $\begin{array}{l}\text { Other cleaning products } \\
\text { (HN011 cluster } 3)\end{array}$ \\
\hline H3. & Kitchen stoves and furnishings & $\begin{array}{l}\text { Stoves and ovens (excluding } \\
\text { microwave ovens) (30031) }\end{array}$ & $\begin{array}{l}\text { Stoves and ovens excluding } \\
\text { microwave ovens } \\
\text { (HK013) }\end{array}$ \\
\hline $\mathrm{H} 4$. & Furniture, chairs, kitchen, plain & Kitchen table, chair and sets & Kitchen table, chair and sets \\
\hline
\end{tabular}




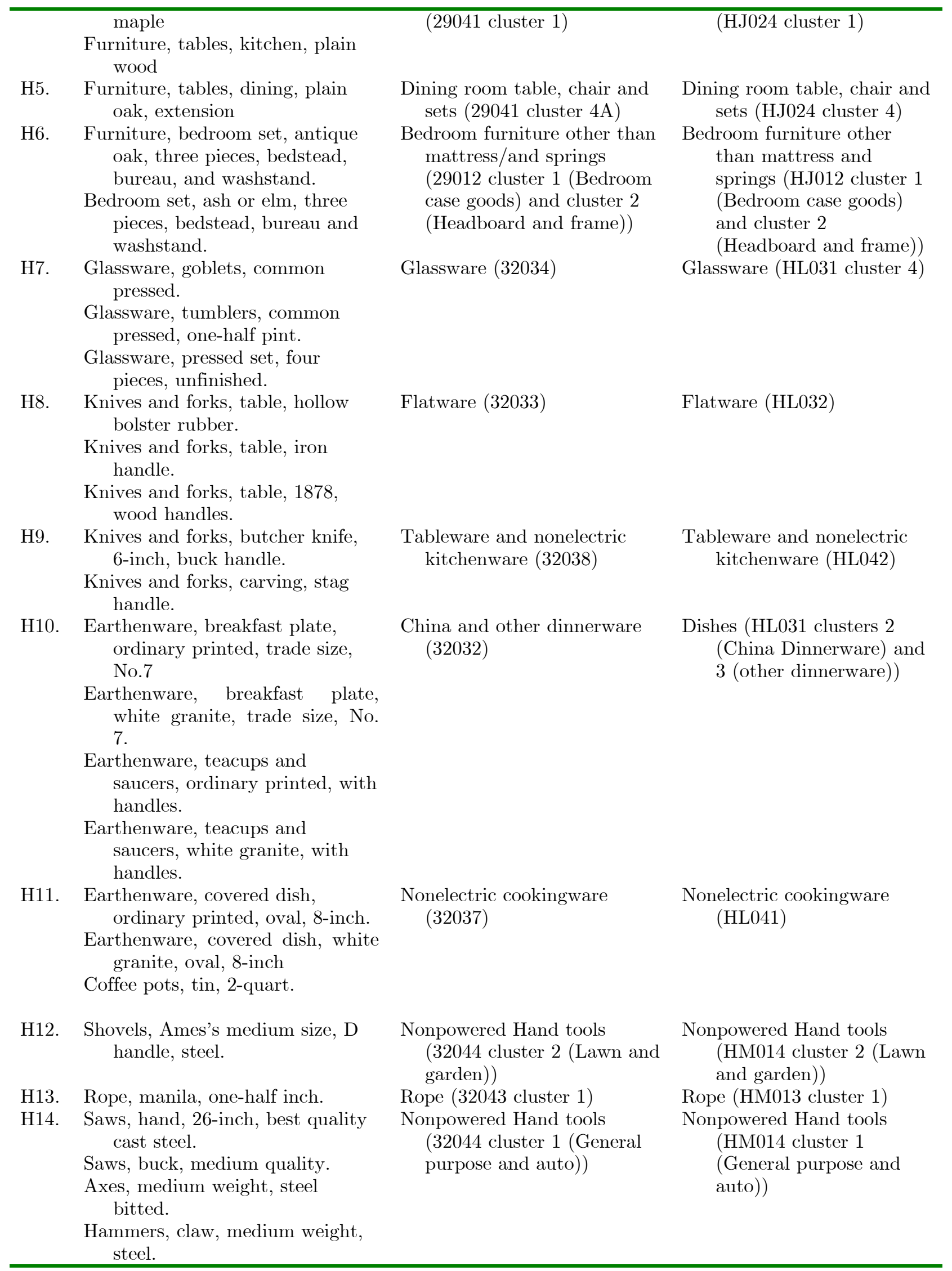




\section{Clothing}

1889-18.91 Product

C1. Underwear, cotton shirts, Balbriggan, 34 gauge.

Underwear, cotton drawers, Balbriggan, 34 gauge.

Underwear, cotton shirts, mixtures, 34 gauge.

Underwear, cotton drawers, mixtures, 34 gauge.

Underwear, men's undershirts, 1416 gauge, all wool, 10.5 pounds per dozen, plain finish.

Underwear, men's drawer's 14-16 gauge, scarlet, all wool, 10.5 pounds per dozen.

Underwear, men's merino shirts, half wool, 16-18 gauge, 10.5 pounds per dozen.

Underwear, men's merino drawers, half wool, 16-18 gauge, 10.5 pounds per dozen.

C2. Hosiery, men's cotton socks, seamless, mixed, 108 needles, weighing 28 ounces to dozen.

Hosiery, men's wool socks, seamless, scarlet, 108 needles, weighing 24 to 26 ounces per dozen.

C3. Hats, men's soft, all wool.

Hats, men's Derby, medium grade.

C4. Linen goods, men's cotton shirts, linen bosoms, 8 by 15 inch, 1800 linen.

C5. Hosiery, women's cotton stockings, black, cut feet, 26 gauge, weighing 24 ounces to dozen.

Hosiery, women's woolen stockings, seamless, black, medium quality, 108 needles, weighing 30 ounces to dozen.

C6. Boots and shoes, heavy rubber boots.

C7. Boots and shoes, men's wax brogans, leather.

Boots and shoes, men's split boots,
1987 CPI Revision

Product Category

(ELI)

Men's underwear (36031 cluster 1e)
1997 CPI Revision Product

\section{Category}

Men's underwear (AA021

cluster 1)
Men's Hosiery (36031 cluster $2 \mathrm{e}$ )

Men's Hats and Caps (36033 cluster $2 \mathrm{~d}$ )

Men's shirts (36041)

Women's pantyhose and stockings (38043 cluster 1d)

Men's waterproof footwear (40011 cluster 4f)

Women's waterproof footwear (40031 cluster $4 \mathrm{~g}$ )

Men's work shoes and boots (40011 cluster 6f)
Men's Hosiery (AA021 cluster 2)

Men's Hats and Caps (AA022 cluster 2)

Men's shirts (AA031)

Women's pantyhose and stockings (AC042 cluster 1)
Men's waterproof footwear (AE011 cluster 4)

Women's waterproof footwear

(AE031 cluster 4)

Men's work shoes and boots (AE011 cluster 6) 


\begin{tabular}{ccc}
\hline leather. & Women's dress and & Women's dress and casual shoes \\
C8. & casual shoes and \\
shoes, leather. & and bots (40031 cluster & \\
& $1 \mathrm{~h})$ & \\
\hline
\end{tabular}




\begin{tabular}{|c|c|c|}
\hline \multicolumn{3}{|c|}{ Table A3. Methodology of Price Quotes } \\
\hline & Aldrich Report & 1997-1999 \\
\hline $\begin{array}{l}\text { How } \\
\text { Quotes } \\
\text { Obtained }\end{array}$ & $\begin{array}{l}\text { "The figures must be for actual sales and } \\
\text { must be taken by you [, the BLS employee,] } \\
\text { from the books of the sales of grocers, } \\
\text { provision dealers, bakers, butchers, clothing } \\
\text { dealers, dry goods, dealers, coal dealers, } \\
\text { hardware dealers, lumber dealers, druggists, } \\
\text { and other tradesmen selling at retail to the } \\
\text { ordinary public." (p. CXIX) }\end{array}$ & $\begin{array}{l}\text { After initial visit "subsequent personal visits } \\
\text { or telephone calls are made monthly [for our } \\
\text { sample of cities]... to ascertain that the item } \\
\text { is still sold and to obtain its current price." } \\
\text { (1997 BLS Handbook of Methods Ch. 17, p. } \\
181 \text { ) }\end{array}$ \\
\hline $\begin{array}{l}\text { Dating of } \\
\text { Quotes } \\
\text { within } \\
\text { month }\end{array}$ & $\begin{array}{l}\text { "The figures should be for the first day or } \\
\text { every month though the period beginning } \\
\text { with June } 1,1889 \text { and end with September } \\
\text { 1, 1891. It may happen that the books show } \\
\text { no sale of a particular good on the first day } \\
\text { of the month; in such a case take the figures } \\
\text { for the date nearest the first day[.]" (p. } \\
\text { CXIX) }\end{array}$ & $\begin{array}{l}\text { Three and six day pricing weeks on average } \\
\text { are supposed to represent the } \\
\text { entire month of sampling. Items are } \\
\text { assigned a pricing week based on field } \\
\text { workload. Rarely does the pricing week } \\
\text { change. (Personal communication, } \\
11 / 2 / 2000 \text { ) }\end{array}$ \\
\hline Delivery & $\begin{array}{l}\text { "You are desired to collect prices only from } \\
\text { firms which make a free delivery of } \\
\text { commodities purchased. If you are obliged } \\
\text { to take them from other firms for lack or a } \\
\text { sufficient number of these the fact should be } \\
\text { stated in your notes." (p. CXX) [Nearly all } \\
\text { the firms quoted offer free delivery.] }\end{array}$ & Stores rarely deliver purchases. \\
\hline $\begin{array}{l}\text { Differing } \\
\text { Quality } \\
\text { of Goods } \\
\text { in Group }\end{array}$ & $\begin{array}{l}\text { "[G]reat care was taken... to describe the } \\
\text { articles fully in that the prices obtained } \\
\text { from all parts of the country at dates might } \\
\text { be fairly and legitimately comparable. To } \\
\text { this end you are strictly required to get } \\
\text { prices for only such kinds and qualities as } \\
\text { are described, if such are obtainable...One } \\
\text { thing, however, must be kept steadily in } \\
\text { mind: Be sure that your prices are for the } \\
\text { kinds and qualities described in on the } \\
\text { blanks. Accept no guesses on this score, or } \\
\text { if you are obliged to accept guesses or to } \\
\text { take figures for qualities different from those } \\
\text { on the list the Department must be so } \\
\text { informed." (p. CXX) }\end{array}$ & $\begin{array}{l}\text { Group definitions (ELIs and occasionally } \\
\text { cluster within an ELI) are not as specific as } \\
\text { in earlier periods. Items with different } \\
\text { specifications are often sampled within a } \\
\text { group. However care is taken to make sure } \\
\text { that same item is sampled in the different } \\
\text { periods if available. }\end{array}$ \\
\hline $\begin{array}{l}\text { Store } \\
\text { Selection }\end{array}$ & $\begin{array}{l}\text { No mention made of store selection except } \\
\text { that under the Delivery section. }\end{array}$ & $\begin{array}{l}\text { Probability of outlet selection proportional } \\
\text { to the amount of expenditures at the outlet. } \\
\text { (1997 BLS Handbook of Methods Ch. 17, p. } \\
\text { 180) }\end{array}$ \\
\hline
\end{tabular}

